\title{
The NMDA Receptor Subunits NR2A and NR2B Show Histological and Ultrastructural Localization Patterns Similar to Those of NR1
}

\author{
R. S. Petralia, Y.-X. Wang, and R. J. Wenthold \\ Laboratory of Neurochemistry, NIDCD, NIH, Bethesda, Maryland 20892
}

\begin{abstract}
Neuronal plasticity associated with learning, memory and development is controlled, in part, by NMDA receptors, which are complexes consisting of the subunit NMDAR1 (NR1) and one or more NMDAR2 subunits (NR2A-NR2D). We made a polyclonal antibody to a C-terminus peptide of NR2A. In analysis of transfected cell membranes, this antibody recognizes NR2A and NR2B, and to a slight extent, NR2C and NR2D. In Western blots of rat brain, the antibody labeled a single band that comigrated with NR2A and NR2B. This antibody (NR2A/ B) did not cross-react with extracts from transfected cells expressing other glutamate receptor subunits, nor did it label non-neuronal tissues. Immunostained sections of rat brain showed significant staining throughout the nervous system, including olfactory bulb, cerebral cortex, hippocampus, caudate-putamen, and many brainstem nuclei, as well as in neurons of spinal cord and sensory ganglia. This widespread distribution of staining was similar to that found with an antibody to NR1, supporting the presence of functional NR1/ NR2 complexes throughout the nervous system. In the cerebellum, in contrast to staining with NR 1 antibody, Purkinje cell staining with NR2A/B antibody was low, indicating that these neurons may lack functional NMDA receptors. EM examination revealed dense staining in dendrites and postsynaptic densities in cerebral cortex and hippocampus, similar to those seen with antibody to NR1. Since functional NMDA receptor complexes at synapses appear to require both NR1 and NR2 subunit proteins for full function, this study provides structural evidence for functional NR1/NR2 receptors in vivo in the nervous system.
\end{abstract}

[Key words: excitatory amino acids, ultrastructure, immunocytochemistry, AMPA, hippocampus, cerebellum]

Glutamate receptors are the most widespread neurotransmitter receptors in the CNS, being involved to some extent in nearly every central neural circuit, as well as in many peripheral circuits (e.g., reviewed by Collingridge and Lester, 1989; Monaghan et al., 1989; Nakanishi, 1992). Glutamate receptors can be divided into four major classes (each containing several subunits), bascd on both structural and pharmacological properties (reviewed by Nakanishi, 1992; Seeburg, 1993): (1) metabotropic glutamate receptors (mGluR1-mGluR7; Nakanishi, 1992; Saugstad et al., 1993; Okamoto et al., 1994); (2 and 3) two classes of ionotropic,

\footnotetext{
Received Feb. 7, 1994; revised Mar. 22, 1994; accepted Apr. 6, 1994.

We thank Drs. M. Schneider and M. Tachibana for reviewing the manuscript, and Drs. S. Heinemann, S. Nakanishi, and P. Seeburg for supplying cDNA clones Correspondence should be addressed to Ronald S. Petralia, Laboratory of Neurochemistry, Building 36, Room 5D-08, NIDCD, NIH, Bethesda, MD 20892.

Copyright (C) 1994 Society for Neuroscience $0270-6474 / 94 / 146102-19 \$ 05.00 / 0$
}

non-NMDA receptors including AMPA ( $\alpha$-amino-3-hydroxy5-methyl-4-isoxazolepropionate) receptors (GluR1-GluR4 or GluRA-GluRD) and kainate receptors (GluR5-GluR7, KA1, KA2); and (4) ionotropic, NMDA receptors.

NMDA receptors are perhaps the most widely studied glutamate receptors because of their direct involvement in neuronal development (e.g., reviewed by Burgoyne et al., 1993) and synaptic plasticity, especially involving long-term potentiation and long-term depression (Kirkwood et al., 1993; reviewed by Malenka and Nicoll, 1993), implicated in learning and memory. NMDA receptors are comprised of two classes of subunits: one subunit of NR1 (or NMDAR1; Moriyoshi et al., 1991) that exists in at least eight splice variants (Anantharam et al., 1992; Nakanishi et al., 1992; Sugihara et al., 1992; Durand et al, 1993; Hollmann et al., 1993; Kusiak and Norton, 1993; Standaert et al., 1993); and four subunits of NR2 (or NMDAR2), that is, NR2A, NR2B, NR2C, NR2D (NR2D-1, NR2D-2) (Monyer et al., 1992; Nakanishi, 1992; Ishii et al., 1993). Similar NR subunits have been described in mouse (Ikeda et al., 1992; Kutsuwada et al., 1992; Meguro et al., 1992; Yamazaki et al., 1992), human (Karp et al., 1993; Planells-Cases et al., 1993), and Drosophila melanogaster (Ultsch et al., 1993). Since when expressed alone, these subunits show little (NR1) or no (NR2) physiological response, it is likely that NMDA receptors exist as heteromeric complexes, containing NR 1 combined with one or more NR2 subunits (Monyer et al., 1992; Nakanishi, 1992; Wafford et al., 1993); pharmacology and physiology of the complex would vary according to different combinations of NR1 variants and NR2 subunits (Stern et al., 1992; Cik et al., 1993; Durand et al., 1993; Hollmann et al., 1993; Ishii et al., 1993; Mori et al., 1993; Raditsch et al., 1993; Wafford et al., 1993). In addition to the NR1/NR2 receptor complexes, which seem to correspond most closely to NMDA receptors described in classical physiological studies, a number of other possible NMDA receptors have been reported (Kumar et al., 1991; Itano et al., 1992; Alford and Dubuc, 1993; Mattson et al., 1993; Smirnova et al., 1993a,b).

Data suggesting that NR1/NR2 complexes form the major functional NMDA receptor class in the nervous system come from in situ hybridization (NR1: Moriyoshi et al., 1991; Shigemoto et al., 1992; Furuyama et al., 1993; Sato et al., 1993; Tölle et al., 1993; Watanabe et al., 1993; NR2: Monyer et al., 1992; Ishii et al., 1993; Tölle et al., 1993; Watanabe et al., 1993) and immunocytochemical (NR1: Brose et al., 1993; Petralia et al., 1994; Siegel et al., 1994) studies, which show that mRNA (NR1, NR2) and protein (NR1 only) for these subunits are widespread throughout the CNS and PNS, consistent with physiological studies identifying functional NMDA receptors in most regions of the nervous system (reviewed by Petralia et al., 1994). 
In this line, immunocytochemical studies have been most useful since they allow confirmation of the presence of the subunit protcin within neuronal processes, especially with ultrastructural localization (Petralia et al., 1994), which can be used, for example, to identify subunits present in specific synaptic populations. In fact, the best morphological evidence for the presence of functional NR1/NR2-type NMDA receptors in the nervous system is the immunocytochemical detection of NR2 because (1) localization of mRNA for an NMDA receptor subunit in a neuron may not always coincide with expression of the protein (Sucher et al., 1993), and (2) NR2 subunits are required for fully functional NMDA receptors (Monyer et al., 1992; Ishii et al., 1993); that is, NR1 protein may be present in neurons that neither contain NR2 nor exhibit functional NMDA receptor channels (e.g., Purkinje cells, discussed in Petralia et al., 1994). Thus, using an NR2 antibody, we show histological and ultrastructural evidence that NRI and NR2A/B proteins are colocalized in many neuronal populations, and are postsynaptic, supporting thcir rolc in NMDA receptor function in vivo.

\section{Materials and Methods}

Antibody production and characterization. A 20 amino acid peptide, corresponding to the C-terminus of NR2A (Fig. 1), was conjugated to bovine serum albumin with glutaraldehyde and used to produce antibodies in rabbits, as previously described (Wenthold et al., 1992). The antibodics werc affinity purificd using the synthetic peptide attached to Activated CH-Sepharose 4B (Pharmacia LKB Biotechnology, Piscataway, NJ). The specificity of the antibodies was determined using immunoblots of rat tissues and transfected cell membranes. The cDNA clones used in this study were kindly provided by the following: NR2ANR2D, KA1, and KA2, Dr. P. Seeburg (Univ. Heidelberg); NMDAR1, Dr. S. Nakanishi (Kyoto Univ.); GluR 1-GluR7, Dr. S. Heinemann (The Salk Institute). cDNAs were transfected into human embryonic kidney cells (HEK-293) as described (Wenthold et al., 1994). Expression of protein in the transfected cells was verified using antibodies specific for each subunit except for GluR5, KA1, and NR2D. The amount of transfected cell membrane sample applied to the gel to characterize the NR2A/B antibody was the amount required to produce an intensely stained band using the respective subunit-specific antibody. Samples wcre preparcd and analyzed by sodium dodecyl sulfate-polyacrylamide gel electrophoresis (SDS-PAGE) as described (Wenthold et al., 1994). Primary antibody was used at $0.5 \mu \mathrm{g} / \mathrm{ml}$. Immunoreactive bands were detected using the ECL detection system (Amersham, Arlington Heights, IL). Molecular weights were estimated using unstained standards, myosin $(200 \mathrm{kDa}), \beta$-galactosidase $(116 \mathrm{kDa})$, phosphorylase B $(97 \mathrm{kDa})$, BSA (66 kDa), and ovalbumin (45 kDa), obtained from Bio-Rad (Richmond, CA). Prestained standards from GIBCO-Bethesda Research Labs were myosin, phosphorylase $\mathrm{B}, \mathrm{BSA}$, and ovalbumin and migrated at $M_{r}=210 \mathrm{k}, 103 \mathrm{k}, 71 \mathrm{k}$, and $46 \mathrm{k}$, respectively. For deglycosylation of receptor in transfected cell membranes, SDS-solubilized membranes were treated as described (Wenthold et al., 1994).

Tissue preparation. Young male Sprague-Dawley rats (111-216 gm) were anesthetized with a $1: 1$ mixture of ketamine and Rompun, and perfused transcardially, as described previously (Petralia and Wenthold, 1992; Petralia et al., 1994), with $0.12 \mathrm{M}$ phosphate buffer (pH 7.2) followed by $4 \%$ paraformaldehyde (in same buffer) with or without $0.1 \%$ glutaraldehyde for light/electron or light microscopy, respectively.

Immunocytochemistry. The most useful NR2A/B antibody concentrations were $0.5-1.5 \mu \mathrm{g} / \mathrm{ml}$ (for both first and second bleeds), with the most commonly used concentration being $1 \mu \mathrm{g} / \mathrm{ml}$. Antibody to NR 1 was used at $3-4 \mu \mathrm{g} / \mathrm{ml}$ for the first bleed (as used in Petralia et al., 1994) and $0.5-1 \mu \mathrm{g} / \mathrm{ml}$ for the second bleed. NR 1 antibodies were run on some sections in most experiments in order to compare results with those obtained with NR2A/B antibody. Only new data on NR1 antibody, that is, not included in Petralia et al. (1994), are mentioned in the results. Also, some sections were immunolabeled with a monoclonal antibody to NRI (provided by Drs. Nils Brose and Stephen F. Heinemann, The Salk Institute; Sucher et al., 1993; Siegel et al., 1994). We used a preembedding immunocytochemical procedure as described in detail previously (Petralia and Wenthold, 1992; Petralia et al., 1994).

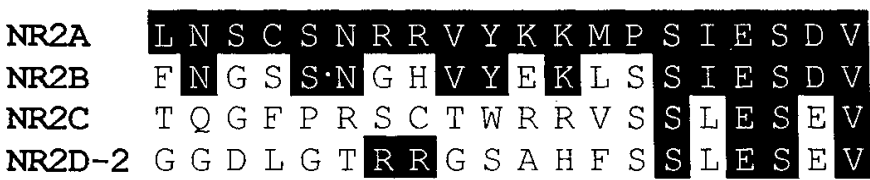

Figure 1. Amino acid sequence of the C-terminus of NR2A used to produce the antibody, compared to C-termini of NR2B, NR2C, and NR2D-2. Identical amino acids in NR2B, NR2C, and NR2D-2 are shown in white letters on black.

Briefly, $50 \mu \mathrm{m}$ sections were blocked in 10\% normal goat serum/PBS, incubated overnight in primary antibody and visualized using an avidin-biotin-peroxidase system (Vectastain kit, Vector Laboratories, Burlington, CA) and 3',3-diaminobenzidine tetrahydrochloride (DAB: 10 $\mathrm{mg} / 20 \mathrm{ml}$ PBS $+5 \mu \mathrm{l} 30 \%$ hydrogen peroxide). Sections for electron microscopy were fixed in 1\% osmium tetroxide and embedded in Poly/ BED 812 resin (Polysciences, Inc., Warrington, PA). Yellow sections (averaging $75 \mathrm{~nm}$ ) were taken from the edge (i.e., perpendicular to the plane of the section) of the $50 \mu \mathrm{m}$ sections on an LKB Ultratome IV ultramicrotome, and examined unstained in a JEOL JEM-100CX II transmission electron microscope.

Controls. Sections in which PBS was substituted for the primary antibody (PBS controls) were run in every experiment for both light and electron microscopy of all structures studied. In addition, three preadsorption control tests were run in which sections were incubated with antibody that was preincubated with specific peptide conjugated to BSA $(50 \mu \mathrm{g} / \mathrm{ml})$, along with appropriate accompanying sections treated with primary antibody (without peptide) and sections with primary antibody and glutaraldehyde-treated BSA $(50 \mu \mathrm{l} / \mathrm{ml}$, without peptide).

Anatomical survey. Basic procedures were as described in previous studies (Petralia and Wenthold, 1992; Petralia et al., 1994). Sagittal sections (17 sides of 13 rats) were taken from up to six levels (PW7985; i.e., corresponding to Figures 79-85 in Paxinos and Watson, 1986). Coronal sections (four rats) were taken from up to 13 different levels, corresponding to figures in PW. Transverse sections from cervical spinal cord (14 rats), cervical dorsal root ganglia (14 rats), trigeminal ganglia (2 rats), pituitary glands (15 rats), and pineal glands (12 rats) were examined. In addition, sections were examined from one female rat (134 gm) and included sagittal sections (one side), cervical spinal cord, pineal gland, and cervical dorsal root ganglia. Thin sections for electron microscopy (two rats) of cerebral cortex, hippocampus and cerebellum were taken from sagittal vibratome sections corresponding to PW8285 as described for the NR1 study (Petralia et al., 1994). All layers of cerebral cortex and cerebellar cortex and CA1/CA2 and CA3 regions of hippocampus were examined with electron microscopy. However, layers of the cerebral cortex were not identified in thin sections.

As described previously (Petralia and Wenthold, 1992; Petralia et al., 1994), choice of optimum antibody concentrations was based on the presence of dense staining in some structures as compared to PBS control sections. Level of staining in Table 1 represents the average of all animals examined, and was based on an arbitrary relative scale where the densest stained structures were assigned a value of 4 , and structures in which staining was not higher than the PBS control were assigned a value of 0 . Designations of staining intensity in the text of "light, moderate, moderately dense, and dense" correspond roughly to table values of 1 , 2, 3, and 4, respectively. Density of staining was compared among structures stained with each antibody (NR1, NR2A/B) but not between the two antibodies. Typically, staining penetrated several micrometers on both sides of the section; lack of staining in the middle of the width of the section was considered in all assessments of light and electron microscope localization of staining. Staining is described as "neuropilar" and "neuronal," as defined in Petralia and Wenthold (1992; see also Petralia et al., 1994); that is, neuronal staining refers to staining of the cell body, excluding nucleus, and the major dendrites that could be traced from the cell body, while neuropilar staining includes processes not traced to specific cell bodies and the unresolvable matrix between cells. Our descriptions of immunostaining in large structures of the brain (e.g., amygdala, hypothalamus, septum, thalamus, etc.) can be considered valid for the portion examined only, since such structures cxtend beyond the sections examined as described above, and as noted previously (Petralia and Wenthold, 1992). Identification of structures with electron microscopy was based on defined criteria (e.g., Peters et al., 1991), as reviewed previously (Petralia and Wenthold, 1992; Petralia et al., 1994). 


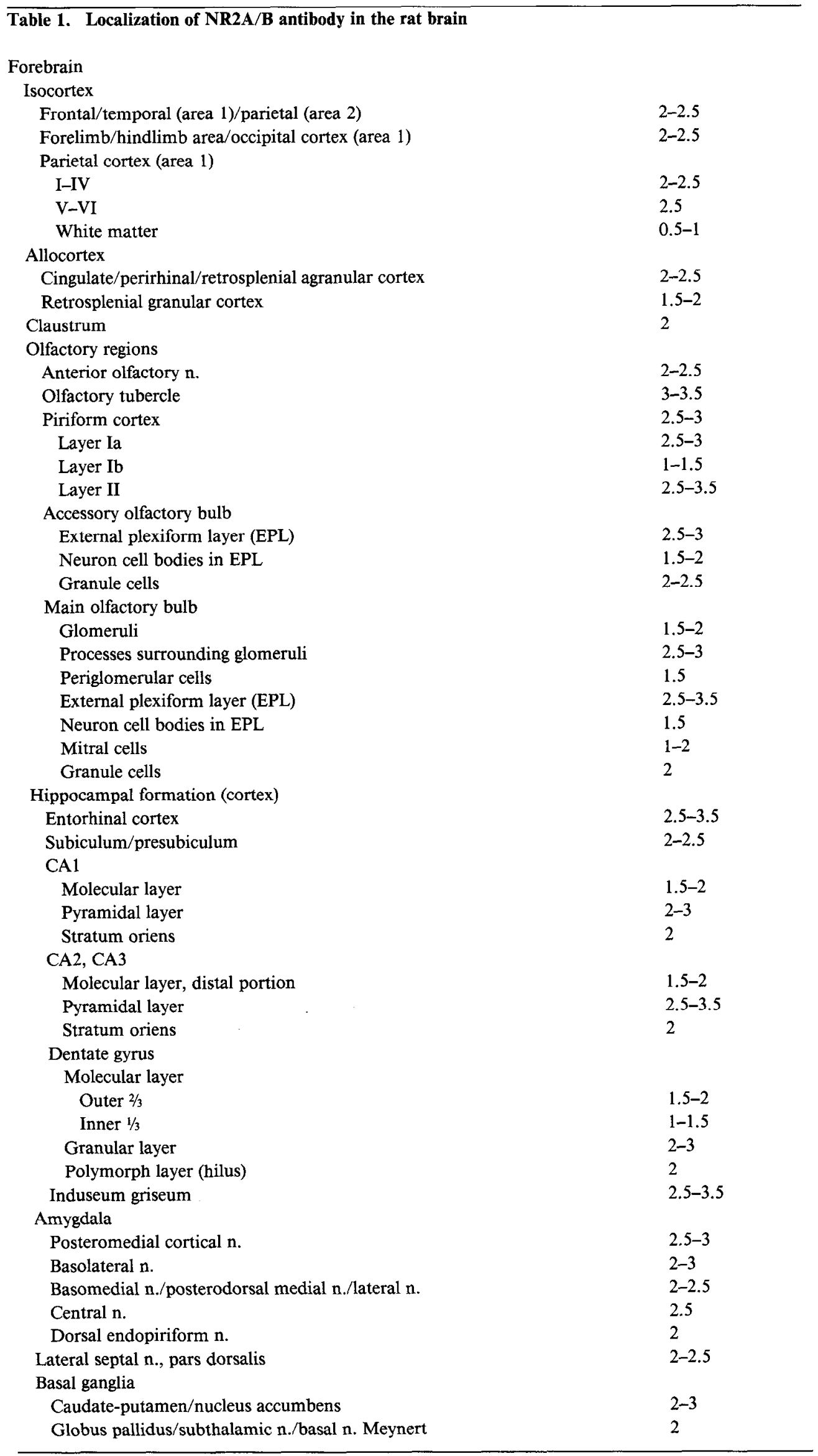




\section{Table 1. Continued}

Horizontal limb of the diagonal band

Vertical limb of the diagonal band

N. fields of Forel/substantia nigra

Epithalamus

Medial habenula

Lateral habenula

Pineal gland

Thalamus

Ventral nuclear group

Lateral nuclear group (laterodorsal/lat. post. n.)

Anterior nuclear group

Anteroventral $\mathrm{n}$./anteromedial $\mathrm{n}$.

Anterodorsal n.

Interanteromedial $\mathrm{n}$.

Posterior n. group

Intralaminar nuclear group

Central medial $n$.

Parafascicular $\mathrm{n}$.

Midline group

Rhomboidal $\mathrm{n}$./reuniens $\mathrm{n}$.

Anterior and posterior paraventricular $\mathbf{n}$.

Reticulothalamic $\mathrm{n}$.

Neurons

Zona incerta

Lateral geniculate $\mathrm{n}$.

Dorsolateral/ventrolateral (magnocellular) $\mathrm{n}$.

Ventrolateral (parvocellular) $\mathrm{n}$.

Medial geniculate (dorsal, medial, ventral) $\mathrm{n}$.

Suprageniculate $\mathrm{n}$.

Hypothalamus

Supraoptic n./arcuate $n$.

Retrochiasmatic portion of the supraoptic $n$.

Paraventricular n., magnocellular portion

Periventricular $\mathrm{n}$./posterior $\mathrm{n} . /$ medial mammillary $\mathrm{n}$.

Suprachiasmatic $\mathrm{n}$./lat. hypothalamic area

Jcn.-median eminence/infundibulum

Pituitary gland

Anterior lobe

Intermediate lobe

Posterior lobe

White matter

Corpus callosum

Internal capsule/optic chiasm/mammillothalamic tract

Supraoptic decussation

Anterior commissure

Anterior

Posterior

Medial lemniscus

Fornix

Stria terminalis
$2-2.5$

2

2-2.5

2.5-3.5

2

3-4

2-2.5

2

2

\section{1}

0.5

1.5

$0.5-1$

$1-2$

$0-0.5$

1.5-2

2

1.5-2

2 


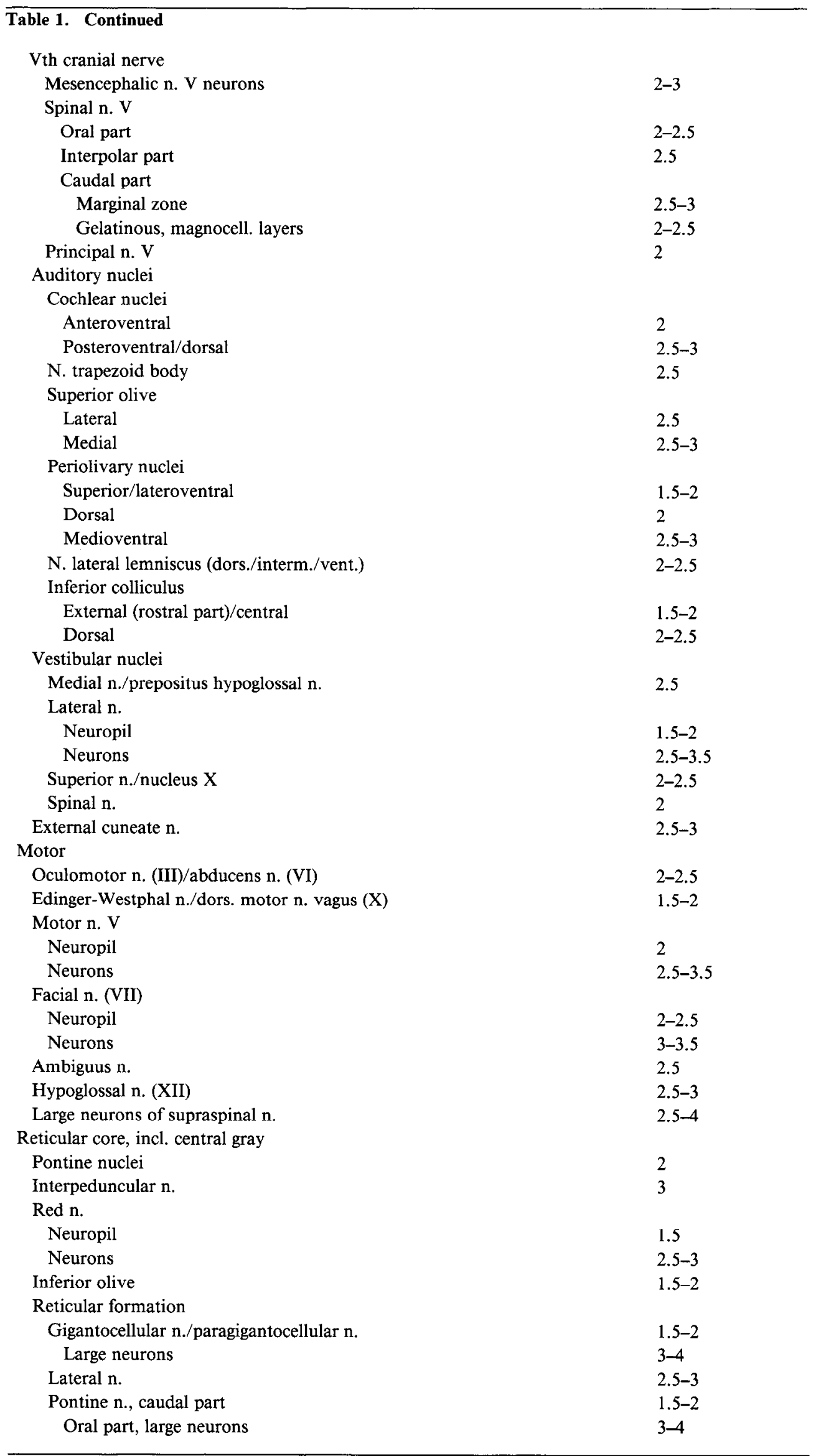




\begin{tabular}{|c|c|}
\hline \multicolumn{2}{|l|}{ Raphe n. } \\
\hline Magnus & 2 \\
\hline Pallidus & $1.5-2$ \\
\hline Mesencephalic central gray & 2 \\
\hline Locus coeruleus & $2.5-3$ \\
\hline White matter (tracts $\mathrm{n} . \mathrm{V}, \mathrm{VII}$ ) & $0.5-1$ \\
\hline \multicolumn{2}{|l|}{ Cerebellum } \\
\hline \multicolumn{2}{|l|}{ Dcep nuclei } \\
\hline Interpositus/medial & $1.5-2$ \\
\hline Lateral & $2-2.5$ \\
\hline \multicolumn{2}{|l|}{ Cortex } \\
\hline Molecular and granular layers & 2 \\
\hline Bergmann glia & $0-0.5$ \\
\hline Purkinje cell bodies & $0-1.5$ \\
\hline Purkinje cell dendrites & $0.5-2$ \\
\hline Molecular layer cells & - \\
\hline Golgi cells & - \\
\hline White matter & 0.5 \\
\hline Glia & $0-0.5$ \\
\hline \multicolumn{2}{|l|}{ Cervical spinal cord } \\
\hline A. Laminae I-III & $3-3.5$ \\
\hline B. Laminae VII-VIII & $1.5-2$ \\
\hline C. Motoneurons of lamina IX & $3-4$ \\
\hline D. Lamina $\mathrm{X}$ & $2-2.5$ \\
\hline \multicolumn{2}{|l|}{ Ganglia } \\
\hline A. Vestibular ganglion cells & $2-3$ \\
\hline B. Trigeminal ganglion cells & $2-3.5$ \\
\hline C. Cervical dorsal root ganglion cells & $2.5-4$ \\
\hline
\end{tabular}

staining. - , staining not evident.

\section{Results}

Immunoblot analysis of membranes of HEK-293 cells transfected with NR2A showed a single immunoreactive band migrating at $M_{r}$ estimated to be 172,000 (Fig. 2a). NR2B showed two immunoreactive bands, one comigrating with NR2A and the second estimated to migrate at an $M_{r}$ of 165,000 . Immunolabeling of both NR2A and NR2B was blocked by previous treatment of the antibody with the synthetic peptide used to produce the antibody (Fig. $2 b$ ). The two immunoreactive bands in the NR2B sample appeared to represent the glycosylated and deglycosylated forms of the protein, since enzymatic deglycosylation with $\mathrm{N}$-glycosidase $\mathrm{F}$ resulted in labeling only at the lower molecular weight (Fig. 2c). This treatment also reduced the size of NR2A to an $M_{r}$ of 165,000 . In addition to the robust recognition of $\mathrm{NR} 2 \mathrm{~A}$ and $\mathrm{NR} 2 \mathrm{~B}$, we saw a minor recognition of NR2C and NR2D-2 (Fig. 2a). The identification of NR2B and NR2C was verified using antibodies selective for NR2B and NR2C, respectively (R. Wenthold, unpublished observation), while the position of NR2D-2 was estimated based on its molecular weight. No interaction was seen with NRI (Fig. 2a) or subunits of non-NMDA receptors (Fig. 2d). Analysis of immunoblots of ral tissues showed labeling of a single band $\mathrm{mi}-$ grating with a $M_{r}$ estimated to be 172,000 (Fig. 3). Labeling was most intense in cortex and hippocampus and light in hindbrain and cerebellum. Staining corresponding to the molecular weight of the NR2C subunit was not seen in cerebellum, even with heavily developed immunoblots. Staining was not seen in nonneuronal samples.

\section{Light microscope distribution}

Immunostaining with antibody to NR2A/B was widespread throughout the nervous system (Figs. 4-9), and the overall distribution in neuronal populations resembled that described for antibody to NR1 (Figs. 4, 6, 8) (Petralia et al., 1994). Many regions contained substantial staining with antibody to NR2A/B in the neuropil, with moderately dense staining in dendrites and puncta, and less staining in neuron cell bodies (Figs. 6, 8). In contrast, staining of the same structures with antibody to NR 1 often was substantial in neuron somas and only light to moderate in neuropil (Figs. 6c, 8d).

The best examples of prominent neuropilar staining with NR2A/B antibody were the external plexiform layer of the olfactory bulb (Figs. $4 b, 6 a$ ) and the cerebral cortex (Fig. 6b,d). In the former, most mitral cell bodies and neuron cell bodies of the external plexiform layer were stained lightly with antibody to NR2A/B, while dendritic processes of all sizes were stained moderately to densely. In the cerebral cortex, pyramidal cell bodies (layers 3 and 5) were stained lightly to moderately while their major apical dendrites were stained moderately to densely. Staining in other neuron somas and dendrites of the cerebral cortex was variable and generally moderate. In comparison, densest staining seen with antibody to NR1 was in the mitral (Fig. 4a) and pyramidal (Fig. 6c) cell bodies of olfactory bulb 


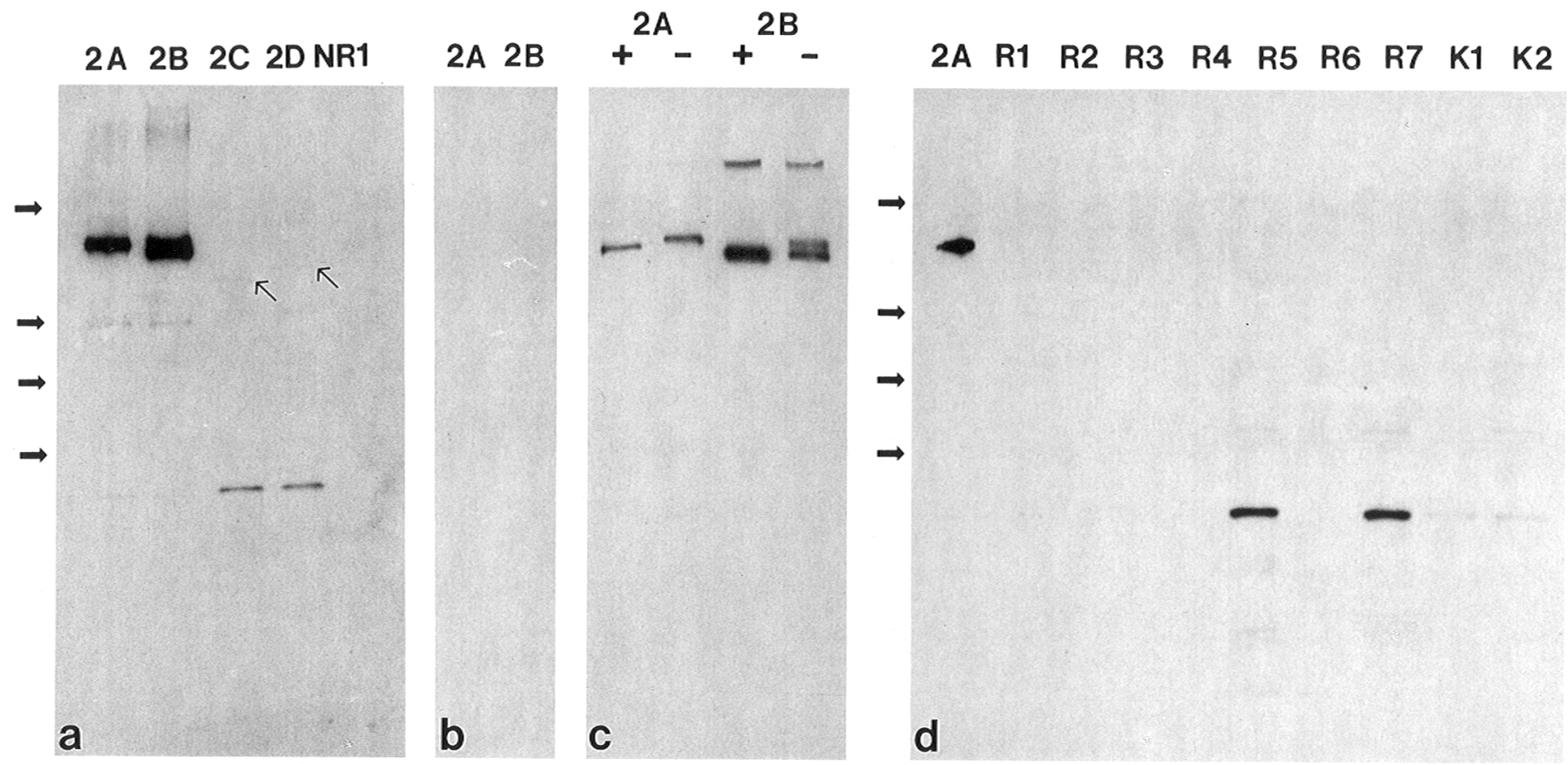

Figure 2. Characterization of NR2A/B antibody using transfected cell membranes. Glutamate receptor subunits were expressed in HEK-293 cells and examined by SDS-PAGE and immunoblot analysis. $a$, Analysis of membranes from cells transfected with NR2A, NR2B, NR2C, NR2D-2, and NR1. Arrows indicate immunoreactive bands identified as NR2C and tentatively identified as NR2D-2. $b$, Immunoblot of NR2A and NR2B using antibody treated with synthetic peptide $(0.5 \mathrm{mg} / \mathrm{ml})$ used to produce the antibody. $c$, Deglycosylated $(+)$ and control $(-)$ samples of NR2A and NR2B transfected cell membranes. $d$, Analysis of NR2A/B antibody interaction with other glutamate receptor subunits, GluR 1-GluR7, KA1, and KA2. Arrows indicate positions of prestained molecular weight standards myosin, phosphorylase B, BSA, and ovalbumin.

\section{OB Cx $\mathrm{H} \quad \mathrm{SC} \quad \mathrm{IC} \quad \mathrm{Hb} \quad \mathrm{Cb} \quad \mathrm{L} \quad \mathrm{M} \quad \mathrm{K}$}

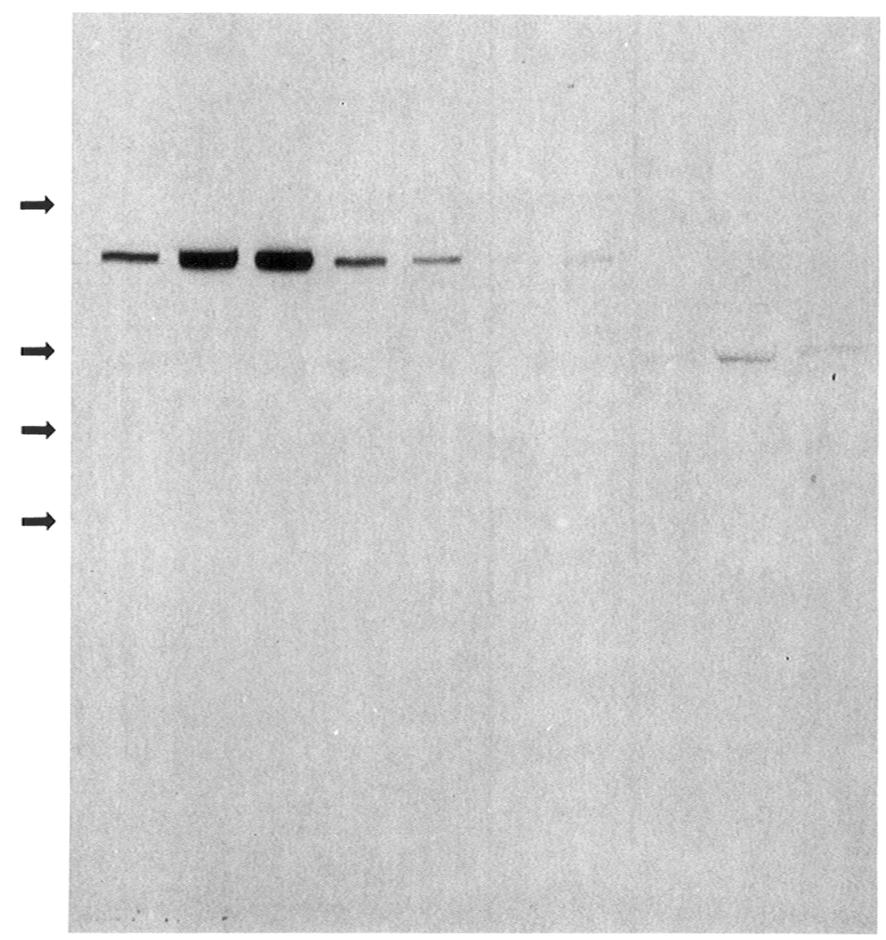

Figure 3. Immunostaining of western blots of rat tissues with antibody to NR2A/B. A single immunoreactive band is seen in neuronal samples including olfactory bulb $(O B)$, cortex $(C X)$, hippocampus $(H)$, superior colliculus $(S C)$, inferior colliculus $(I C)$, hindbrain $(H b)$, and cerebellum $(C b)$ while staining is absent in liver $(L)$, muscle $(M)$, and kidney $(K)$. Thirty micrograms of protein were applied to each lane. Arrows indicate positions of prestained molecular weight standards myosin, phosphorylase B, BSA, and ovalbumin. and cerebral cortex, respectively. In the hippocampus (Fig. 7), staining with antibody to NR2A/B was denser in the stratum oriens than in the molecular layer of CA1-CA3, although the molecular layer often bore a greater number of distinctive puncta. A dense band of staining that probably represents the mossy fibers was found in the stratum lucidum area of CA3 (Fig. 7c), as described for antibodies to NR1 (Petralia et al., 1994; Siegel et al., 1994); its presence was more definitive and consistent with NR2A/B than with NR1. Staining for antibody to NR2A/B in the outer two-thirds of the molecular layer of the dentate gyrus often was slightly denser than that of the inner one-third of this layer (Fig. 7d). This is opposite of the typical pattern seen for antibody to NR1. In the caudate/putamen (Figs. 4, 5a, $8 b$ ), medium-sized neurons were lightly to moderately stained, while most large neurons stained lightly. In contrast, medium and large neurons often were stained moderately densely with antibody to NR1. In some sections stained with the latter antibody, staining in a few large neurons was distinctly denser than in most medium-sized neurons (Fig. 8a).

Neurons in most nuclei of the thalamus were stained lightly to moderately in a lightly stained neuropil. Exceptions include the reticulothalamic nucleus (Fig. $8 c$ ), which contained moderately dense to densely stained neurons; anterodorsal nucleus with moderately dense stained neurons and moderate neuropil; and medial habenula, with lightly to moderately stained neurons and moderately to moderately dense stained neuropil (Fig. 8e). In comparison, moderately dense staining neurons were common in a greater number of thalamic nuclei with antibody to NR1, although staining typically was only moderate in neurons of the reticulothalamic nucleus. In the hypothalamus, densest staining for antibody to NR2A/B was found in neurons of the supraoptic (Figs. 4b, 5a), retrochiasmatic, and magnocellular 

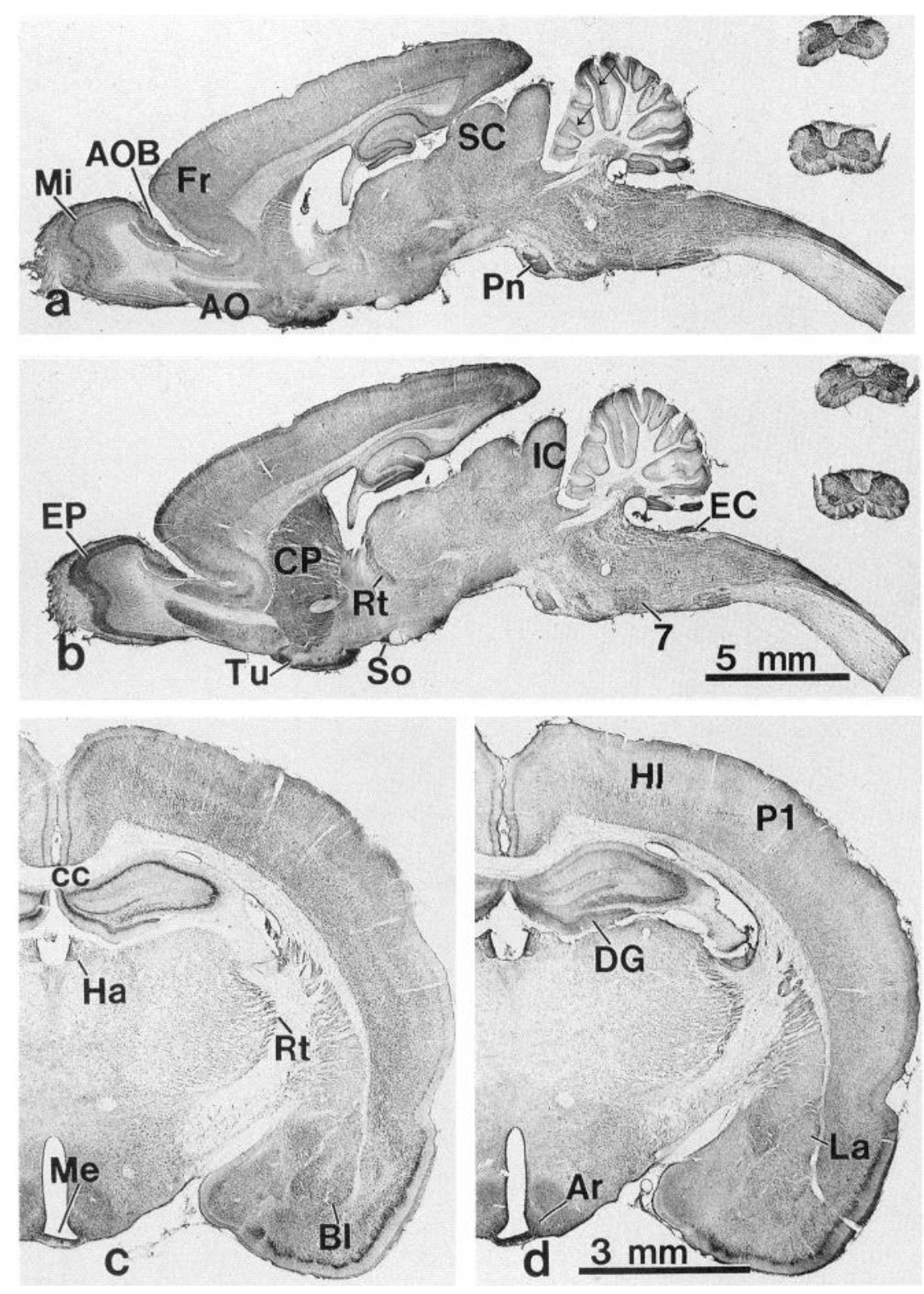

Figure 4. Low magnifications of sagittal sections $(a, b)$, corresponding approximately to Figure 80 of Paxinos and Watson (1986; i.e., PW80), and coronal sections (about PW29-30) $(c, d)$, immunolabeled with antibody to NR2A/B $(b, d)$ and antibody to NR1 $(a, c)$. Transverse sections of cervical spinal cord are seen in the upper right of $a$ and b. Small arrows, Purkinje cell layer of cerebellum. $A O$, Anterior olfactory n.; $A O B$, accessory olfactory bulb; $A r$, arcuate hypothalamic n.; $B l$, basolateral amygdaloid $\mathrm{n}$; $c c$, corpus callosum; $C P$, caudate-putamen; $D C$, dorsal cochlear n.; $D G$, dentate gyrus; $D H$, outer dorsal horn; $E C$, external cuneate n.; $E P$, external plexiform layer of olfactory bulb; $\mathrm{Fr}$, frontal cortex; $\mathrm{Ha}$, habenula; $\mathrm{Hl}$, hindlimb area of cortex; $I C$, inferior colliculus; $1 O$, inferior olive; In, interposed cerebellar n.; $L a$, lateral amygdaloid n.; $L D$, lateral septal n., dorsal part; $M e$, median eminence; $M i$, mitral cell layer of olfactory bulb; $M n$, motoneurons of ventral horn; $o x$, optic chiasm; $P i$, piriform cortex; $P n$, pontine $\mathrm{n}$; $P 1$, parietal cortex, area $1 ; R t$, reticulothalamic n.; $S C$, superior colliculus; $S c$, suprachiasmatic n.; $S o$, supraoptic n.; $S 5 C$, spinal trigeminal n., caudal part; $T u$, olfactory tubercle; $V C$, ventral cochlear n.; 7 , facial n.; 8 , auditory nerve; 12 , hypoglossal n.; $I I I$, third ventricle; $I V$, fourth ventricle. In all light microscope figures (4-9), dorsal is to the top and rostral is to the left (sagittal sections) unless otherwise stated. Magnification: $a$ and $b, 3.6 \times ; c$ and d, $7.1 \times$. paraventricular nuclei as described for antibody to NR1 (Petralia et al., 1994), although staining reached only moderately dense levels with NR2A/B antibody compared to dense levels with NR1 antibody. Both neurons and neuropil of the suprachiasmatic nucleus (Fig. $5 a$ ) were stained lightly to sometimes moderately with antibody to NR2A/B, while they were stained moderately with antibody to NR1. In the arcuate nucleus/median eminence region (Figs. $4 d, 8 g, h$ ), sections immunolabeled with antibody to NR2A/B bore numerous dense puncta in the external layer of the median eminence. Smaller puncta were dot-like while larger ones often were shaped like irregular rings. These puncta often were arranged in long trains, presumably reflecting their regular placement along an unstained process, which was sometimes visible. Such puncta were uncommon and less definitive in the internal layer of the median eminence and arcuate nucleus. In contrast, with antibody to NR1, similar puncta were common in the internal layer of the median eminence and arcuate nucleus, and were rare in the external layer of the median eminence (origin of the pituitary portal system; for example, Armstrong, 1985) (Fig. $8 f$ ). Staining was prominent in all lobes of the pituitary with both antibodies, although it was densest in the anterior and posterior lobes with antibody to NR2A/B and in the intermediate lobe with antibody to NR 1 (Petralia et al., 1994).

Immunostaining was prominent and similar overall with both antibodies throughout many nuclei in the midbrain and hindbrain (Table 1, Fig. 9a,b), including the dorsal cochlear (Fig. $5 b$ ), lateral vestibular (Fig. $9 a$ ), trigeminal motor (Fig. $9 b$ ), facial, supraspinal nuclei, large multipolar neurons of the deep layers of the superior colliculus, a few large multipolar neurons in the external cortex of the inferior colliculus, and large neurons of some medial reticular nuclei such as the gigantocellular and paragigantocellular nuclei. Staining of neurons in some nuclei, such as the dorsal motor nucleus of the vagus, hypoglossal nucleus, inferior olive, and locus coeruleus, typically was light with NR2A/B antibody compared to a moderate or moderately dense 

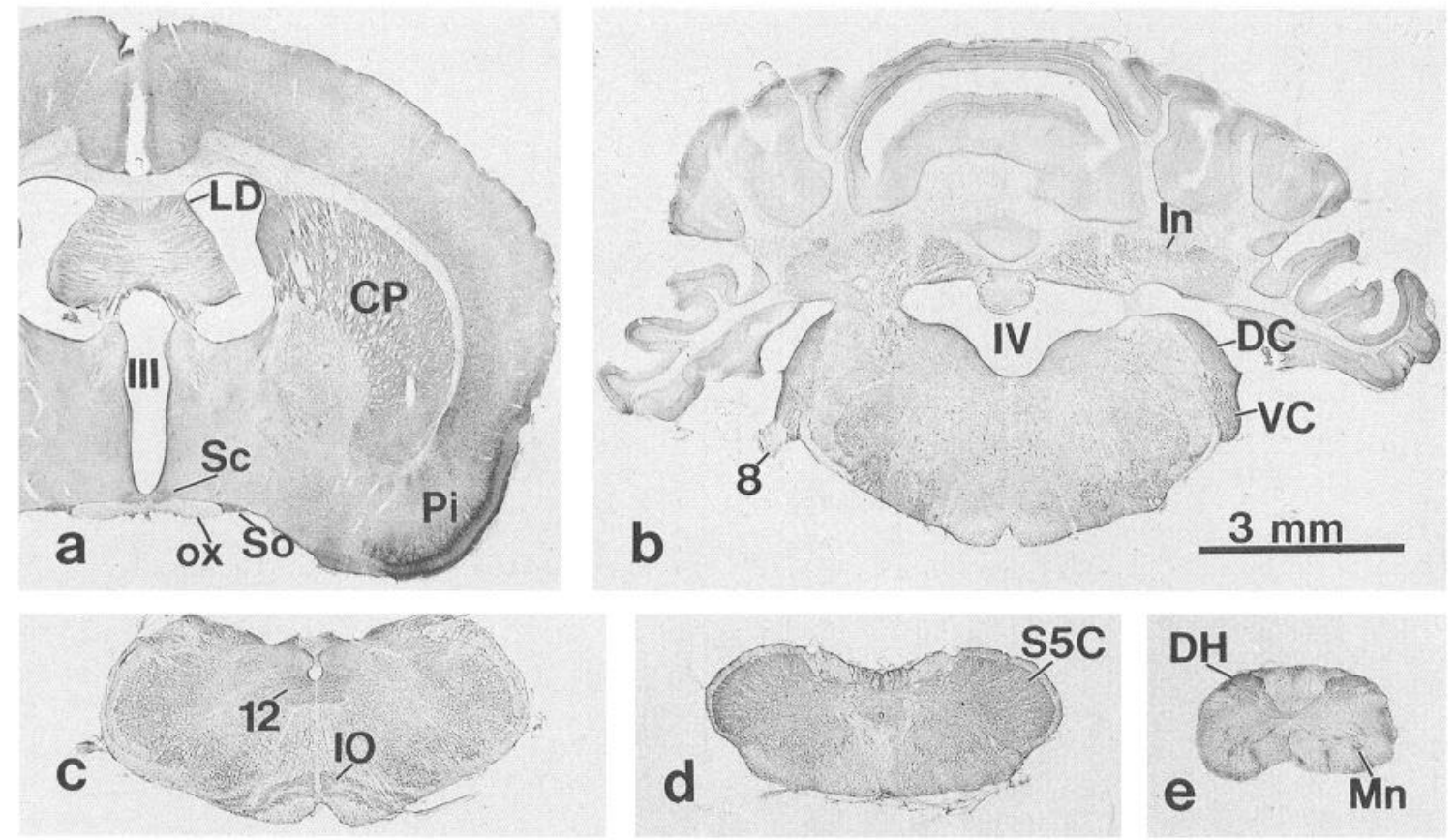

Figure 5. Low magnifications of coronal sections immunolabeled with antibody to NR2A/B, arranged from rostral forebrain (a) to cervical spinal cord $(e)$. Abbreviations are as defined for Figure 4. Magnification: 7.1×.

staining with NR1 antibody (Petralia et al., 1994); although neuropilar staining was moderate with both antibodies. Staining with antibody to NR2A/B of the cortex of the cerebellum was moderate overall, in both granular and molecular layers (Figs. $4 b, 5 b, 9 c)$. Purkinje cell staining with NR2A/B antibody varied from unstained to lightly stained (Figs. $4 b, 5 b, 9 c$ ), in contrast to staining with antibody to NR1 in which the Purkinje cell bodies were stained densely (Fig. 4a) (Petralia et al., 1994). Staining with antibody to NR2A/B was prominent in the pinceau (Fig. 9c), that is, a complex structure consisting mainly of a branched, convoluted basket cell axon surrounding the proximal portion of the Purkinje cell axon (Palay and Chan-Palay, 1974). Staining of this structure was not evident with antibody to NR1. Staining in the cervical spinal cord was most prominent in lamina IX and dorsal horn. In lamina IX, many large motoneurons were stained moderately dense to densely, and the moderately stained neuropil contained numerous, large, dense puncta (Fig. 9d). Neurons in most other laminae (V-VIII) were stained lightly or were unstained. In contrast, many neurons in these lamina stained moderately with antibody to NR 1 (Petralia et al., 1994). In cranial (vestibular, trigeminal) and spinal ganglia, neurons of all sizes stained moderately to densely with antibodies to NR1 and NR2A/B.

No definitive differences in staining pattern were seen between sections from male rats and a limited number of sections from a female rat, although it is likely that some differences in NMDA receptors exist between sexes (Akinci and Johnston, 1993; Hönack and Löscher, 1993).

\section{Electron microscope distribution}

Immunostaining with antibody to NR2A/B was dense in many dendrites throughout the cerebral cortex, hippocampus, and cerebellar cortex. Staining was less dense in cell bodies and other dendrites and consisted of patches of staining. These patches were associated with microtubules, vesicles, rough endoplasmic reticulum, Golgi, and the surfaces of mitochondria and the nuclear envelope, as described for immunolabeling with antibody to NR 1 (Petralia et al., 1994). Immunostaining of synapses usually was limited to the postsynaptic density and membrane and associated cytoplasm, with no staining in the synaptic cleft and little or none in the presynaptic terminal, which contained round or pleomorphic (mostly round) vesicles. Absence of staining in the cleft supports an intracellular location of the C-terminus of NR2, as suggested for NR1 (Tingley et al., 1993; Petralia et al., 1994). Although staining was usually only postsynaptic, a light staining was found rarely in presynaptic terminals but was not definitive. In spine synapses, staining typically extended throughout the entire spine head and into the neck, and sometimes was very dense. There was no clear evidence of staining in glia although some of the small, stained, unidentified processes could be parts of glial cells. Other stained structures included the inner surface of blood vessels and, occasionally, myelinated axons (as noted for CA1-hippocampal myelinated axons with antibodies to AMPA receptors; Martin et al., 1993).

In the cerebral cortex (Fig. 10), stained dendrites and synapses were found throughout the gray matter with antibody to NR2A/ B. Among postsynaptic densities with definitive staining, dense staining (Fig. $10 b, c$ ) was seen more commonly with NR2A/B antibody than with NR1 antibody (Petralia et al., 1994). One example of dense immunolabeling of a presynaptic terminal was seen, but structural details were obscured by the staining.

In the hippocampus (Fig. 11), densely stained postsynaptic densities and spines were found commonly in stratum oriens (Fig. 11a,b) and molecular layer (Fig. 11c,d) of both the CA1/2 and $\mathrm{CA} 3$ regions. In the stratum lucidum, staining sometimes was seen in postsynaptic densities of specialized spines of mossy fiber synapses (Fig. 11e). While this staining was not common, it varied from light to dense, compared to the light staining seen uncommonly in similar synapses with antibody to NR 1 (Petralia et al., 1994). In addition, patches of staining were found in 

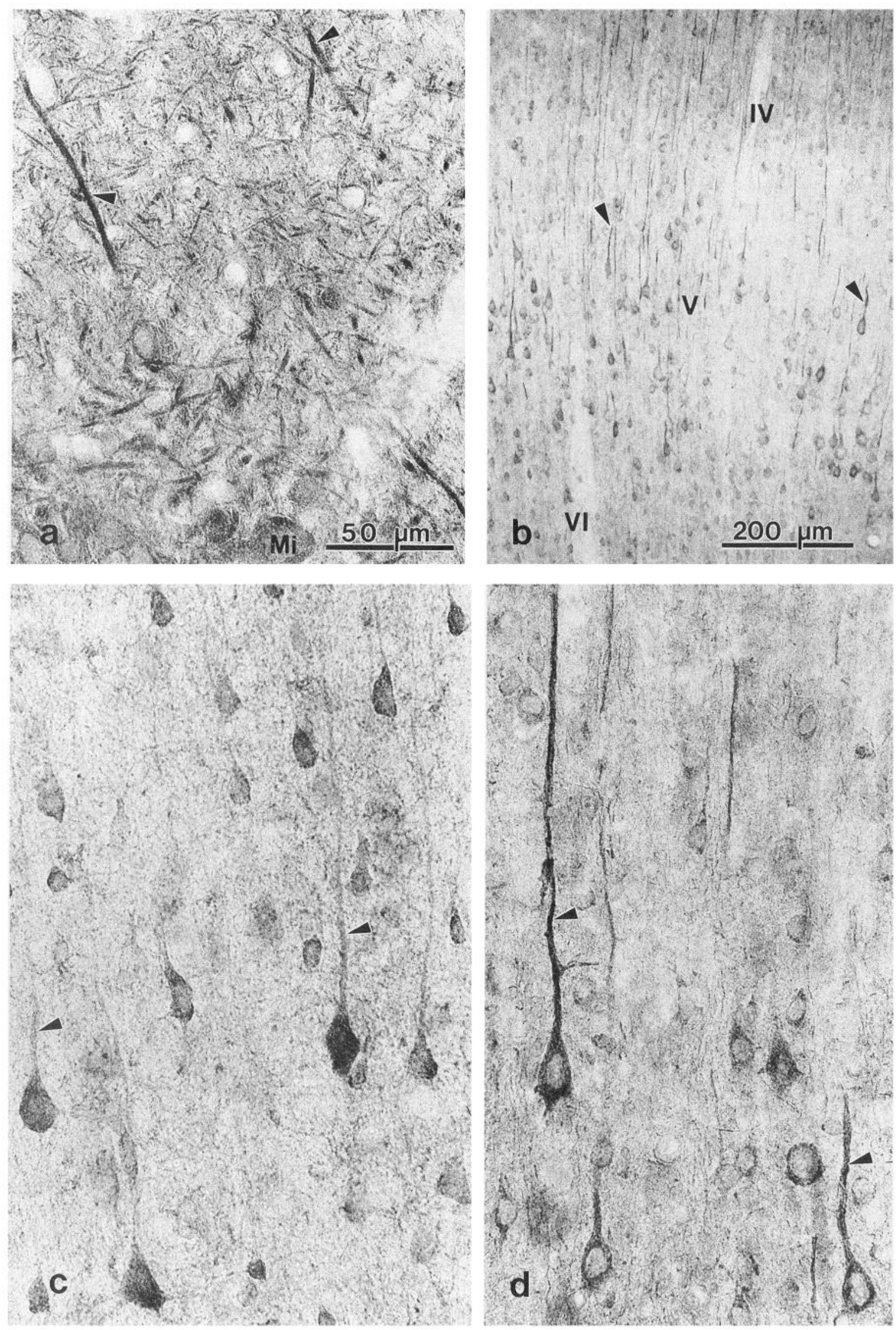

Figure 6. Olfactory bulb and cerebral cortex labeled with antibody to NR2A/B $(a, b, d)$ or NR1 $(c)$. $a$, Sagittal section of external plexiform layer of olfactory bulb. $M i$, mitral cell; arrowheads, dendrites. $b$, Coronal section of hindlimb area of cerebral cortex. $I V-V I$, layers IV-VI. $c$ and $d$, Coronal sections of layer $\mathrm{V}$ of hindlimb/parietal area of cerebral cortex (caudal to area in $b$ ), labeled with antibody to NR1 (c) and NR2A/B $(d)$. Arrowheads, apical dendrites of pyramidal cell. Magnification: $a, c$, and $d, 438 \times ; b, 114 \times$. 

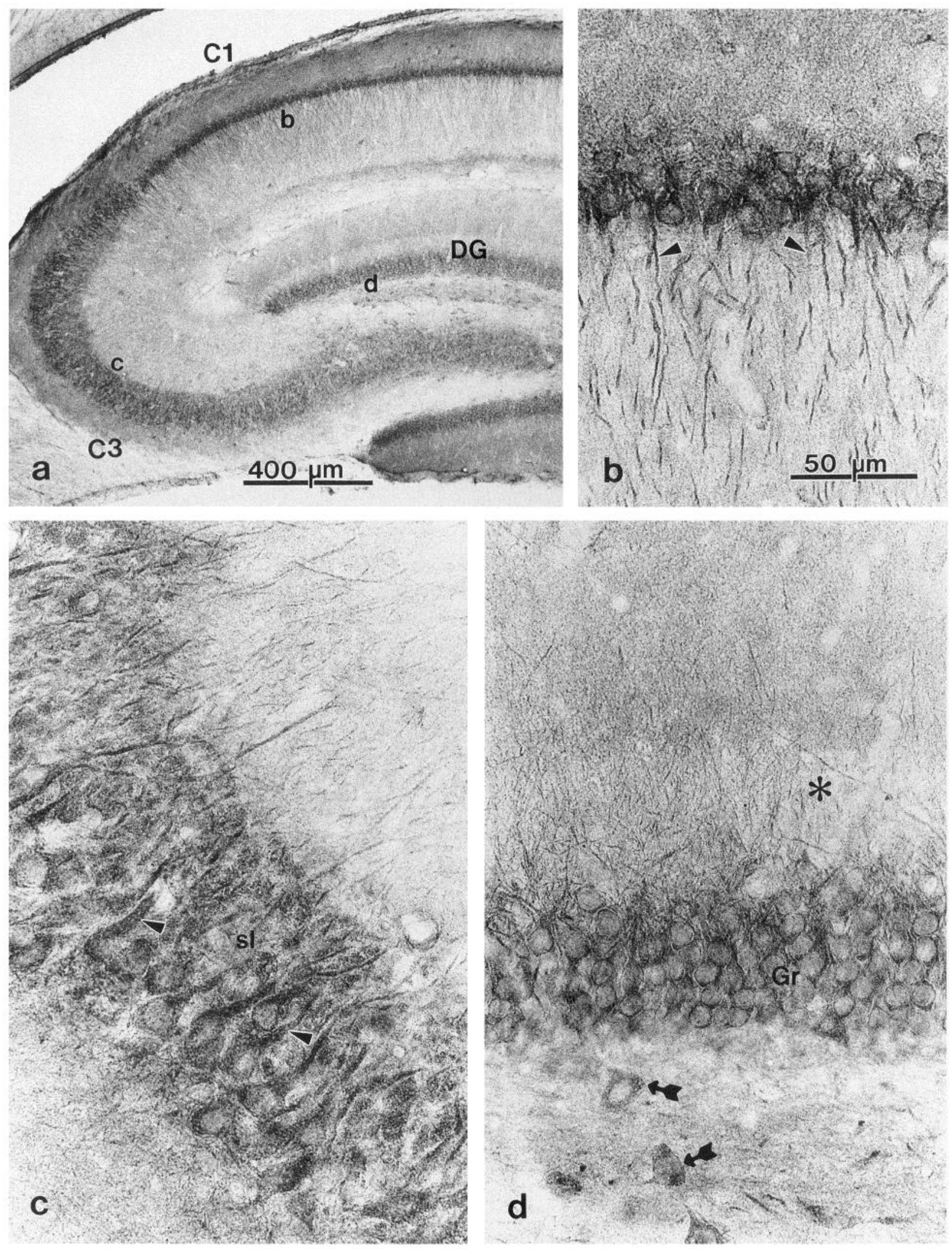

Figure 7. Sagittal sections of hippocampus labeled with antibody to NR2A/B. $a$, Low magnification of rostral two-thirds of hippocampus. Areas labeled $b-d$ are shown at higher magnifications in panels $b-d$. $b$, CA1 region. $c$, CA3 region. $d$, Dentate gyrus. $C 1$ and $C 3$, CA1 and CA3 regions; $D G$, dentate gyrus; $G r$, granule cells of dentate gyrus; sl, stratum lucidum; arrows, hilar cells; arrowheads, apical dendrite of pyramidal cells; asterisk, lighter-stained proximal third of molecular layer of dentate gyrus. Magnification: $a, 56 \times ; b-d, 438 \times$. 

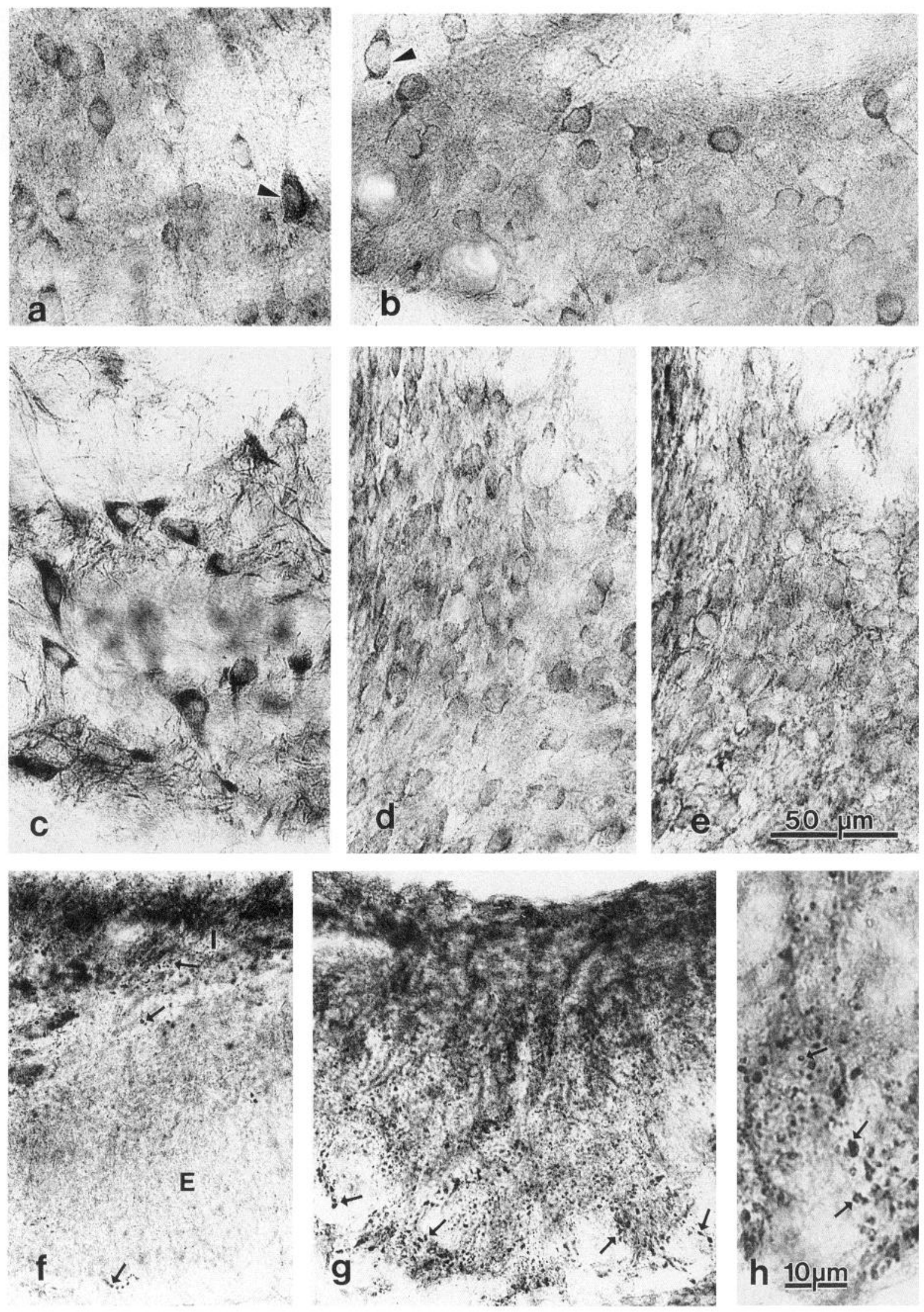

Figure 8. Striatum, thalamus, and median eminence labeled with antibodies to NR1 $(a, d, f)$ or NR2A/B $(b, c, e, g, h) . a$ and $b$, Coronal sections of caudate/putamen labeled with antibody to NR1 $(a)$ or NR2A/B $(b)$. Arrowheads, large cells. $c$, Sagittal section of reticulothalamic nucleus (NR2A/ B). $d$ and $e$, Coronal sections of habenula labeled with antibody to NR1 $(d)$ or NR2A/B $(e)$. $f-h$, Coronal sections of median eminence labeled with $\mathrm{NR} 1(f)$ or NR2A/B $(g, h)$. Note different patterns of punctate staining in external $(E)$ and internal $(I)$ layers. Arrows, puncta. Magnification: $a-$ $g, 438 \times ; h, 1062 \times$. 

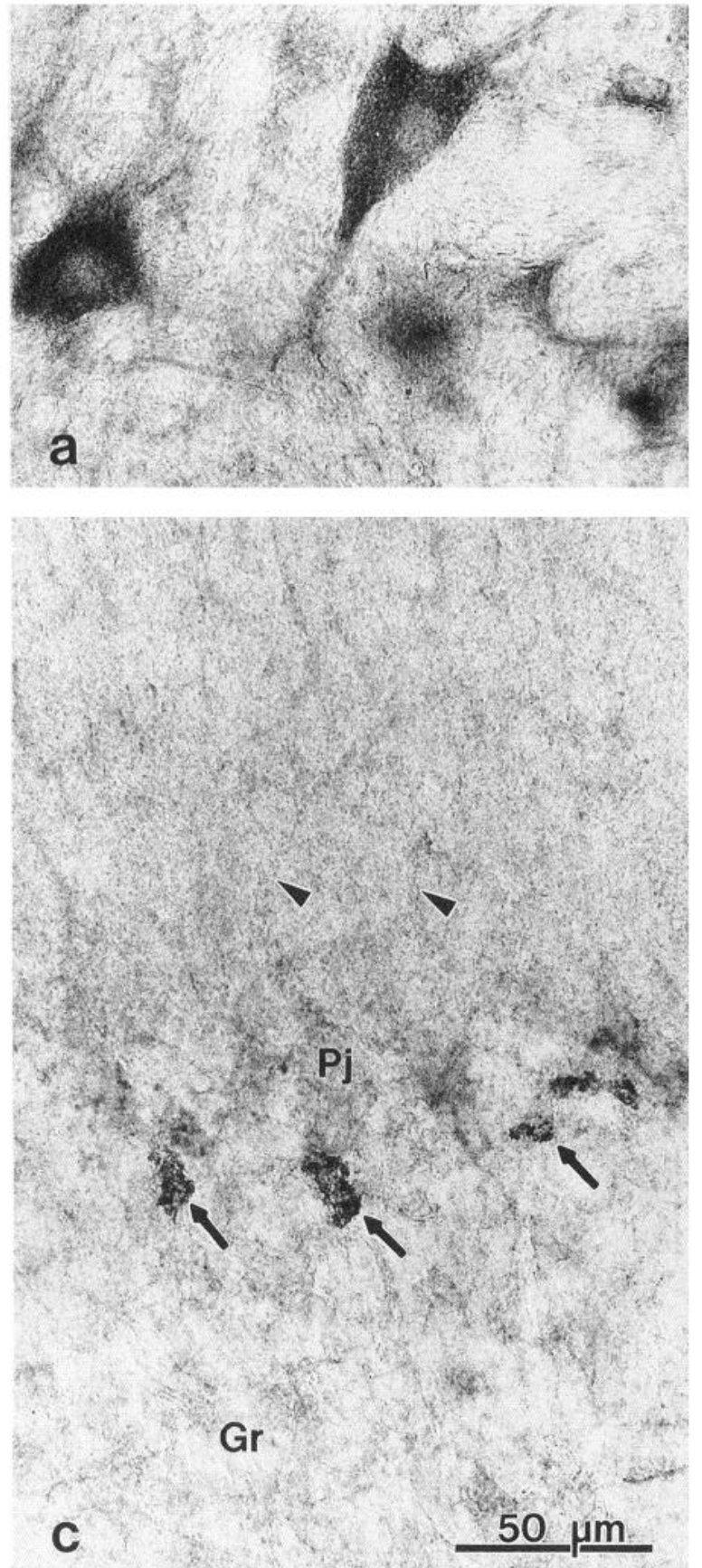
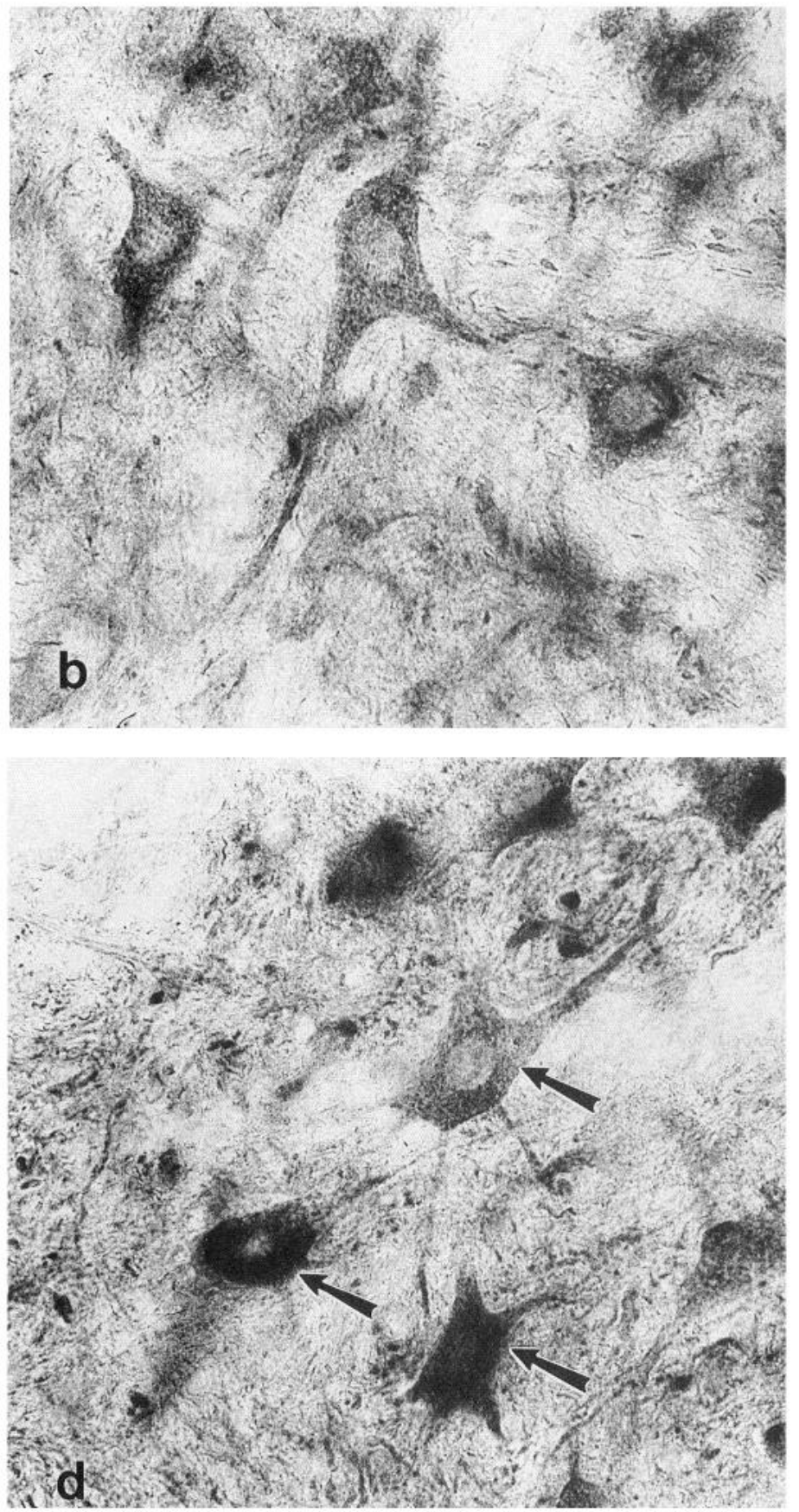

Figure 9. Hindbrain and spinal cord. Sagittal sections of lateral vestibular nucleus (a), trigeminal motor nucleus (b), cerebellar cortex (dorsal is to the left, rostral is to the bottom) (c), and transverse section of lamina IX of cervical spinal cord (d), labeled with antibody to NR2A/B. $G r$, granular layer; $P j$, Purkinje cell; arrowheads, Purkinje cell dendrites; small arrows, pinceau; large arrows, motoneurons. Magnification, $438 \times$.

unmyelinated axons (Fig. 11g), which were found in bundles, that is, presumptive mossy fibers as described in Petralia et al. (1994; see also Siegel et al., 1994). Definitive staining was not found in presynaptic mossy fiber terminals, although patches of staining were seen sometimes.

In the cerebellar cortex (Fig. 12), patches of immunostaining were found in some Purkinje cell bodies and dendrites. Postsynaptic staining in presumptive Purkinje cell spines (i.e., longnecked spine with postsynaptic density on side of head) apposed by parallel fibers (Mugnaini, 1972; Palay and Chan-Palay, 1974) was definitive but not common. Other occasional stained post- synaptic densities were on short, wide spines or on main dendritic shafts, probably from small neurons. In the granular layer, a few patches of staining were found in the cytoplasm of granule cell somas (Fig. 12a) and in dendritic processes in glomeruli. While some of the latter staining extended to the adjacent cell membrane apposed to the presynaptic mossy terminal, definitive staining of postsynaptic membranes and densities in glomeruli was not apparent. Typically, mossy fiber terminals in the glomeruli were not stained although portions of the terminal sometimes were stained lightly. Dense staining was found in cytoplasm and cell membrane of many processes of the pinceau 

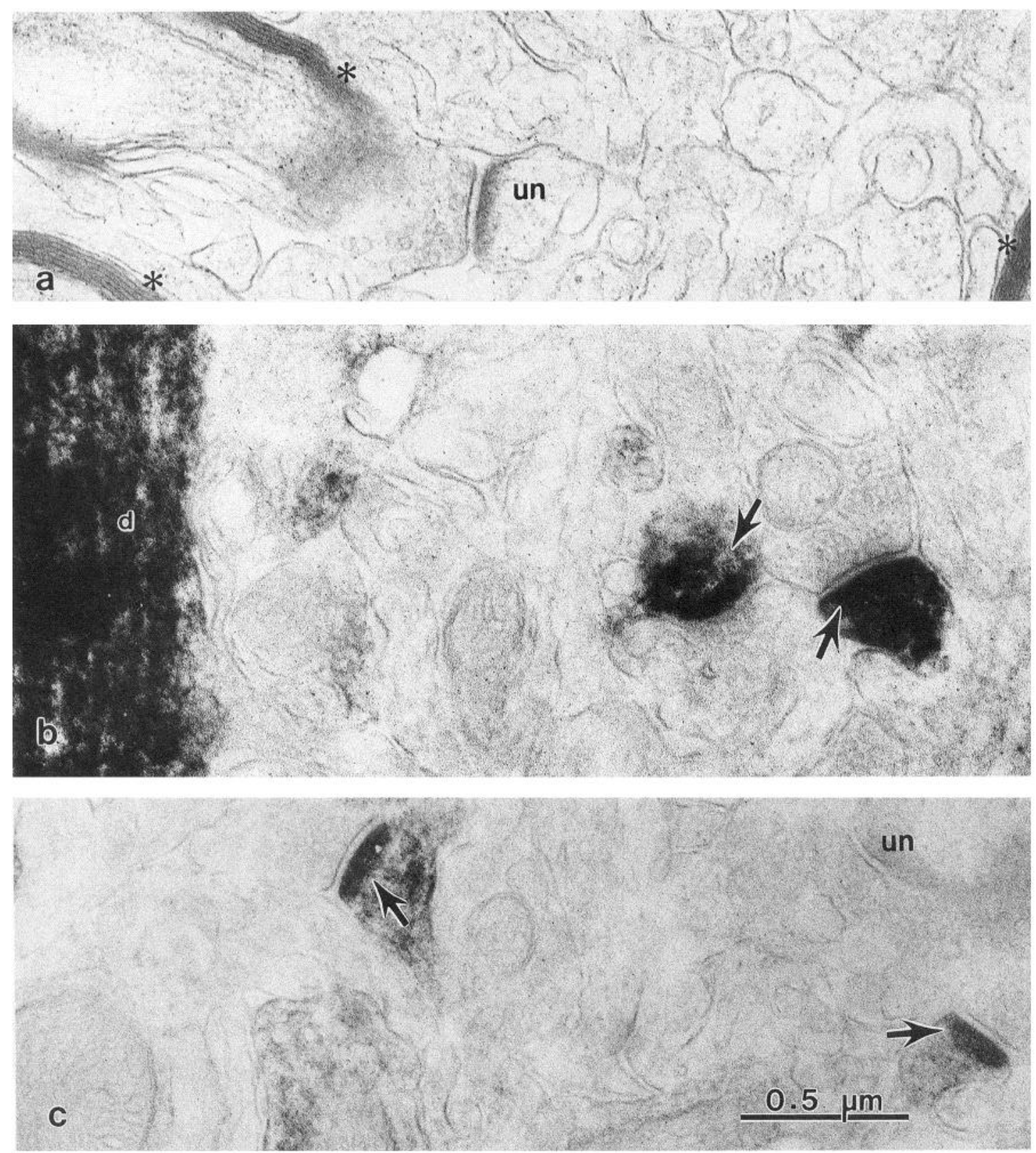

Figure 10. Electron micrographs of cerebral cortex. Immunostaining with antibody to NR2A/B is shown in $b$ and $c . a$, Control section (no primary antibody) shows complete absence of immunostaining in synapse ( $\mathrm{un}$; this example was one of the densest found; most were lighter). Note moderate staining in myelin (asterisks). $b$ and $c$, Dense staining was found in dendrites $(d)$ and in postsynaptic densities (arrows) and adjacent cytoplasm of dendritic spines. un, unstained synapse. Magnification, 50,000×.

(Fig. 12a). In addition, staining was found in patches in unmyelinated fibers found in bundles in the molecular layer (Fig. $12 b$ ), that is, presumed parallel fibers, as described for staining with antibody to NR1 (Petralia et al., 1994).

\section{Controls}

Staining was absent from PBS control sections. Preadsorption control sections were unstained except for a very light staining in some cells and processes, notably the trigeminal sensory, lateral reticular, pontine, supraoptic, and dorsal cochlear nuclei, and sometimes Purkinje cells. In addition, staining in the pineal gland, posterior pituitary lobe and glia of the peripheral white matter of the spinal cord was only slightly reduced by preadsorption. Corresponding experimental sections (i.e., no peptide) were stained normally. Staining was absent from PBS control thin sections of cerebral cortex, hippocampus, and cerebellar cortex examined with electron microscopy (Figs. 10a, 11f), except for myelin sheaths of axons (Fig. 10a) and large, multivesicular body-like structures, as described for NR1 (Petralia et al., 1994). As in the NR1 study, synapses were never stained except for a few of the small spine synapses, which bore lightly stained postsynaptic densities, in the stratum oriens and molecular layer of the hippocampus. None of the latter possessed dense staining as seen with NR2A/B antibody in postsynaptic densities and cytoplasm of small spine synapses of these regions. 

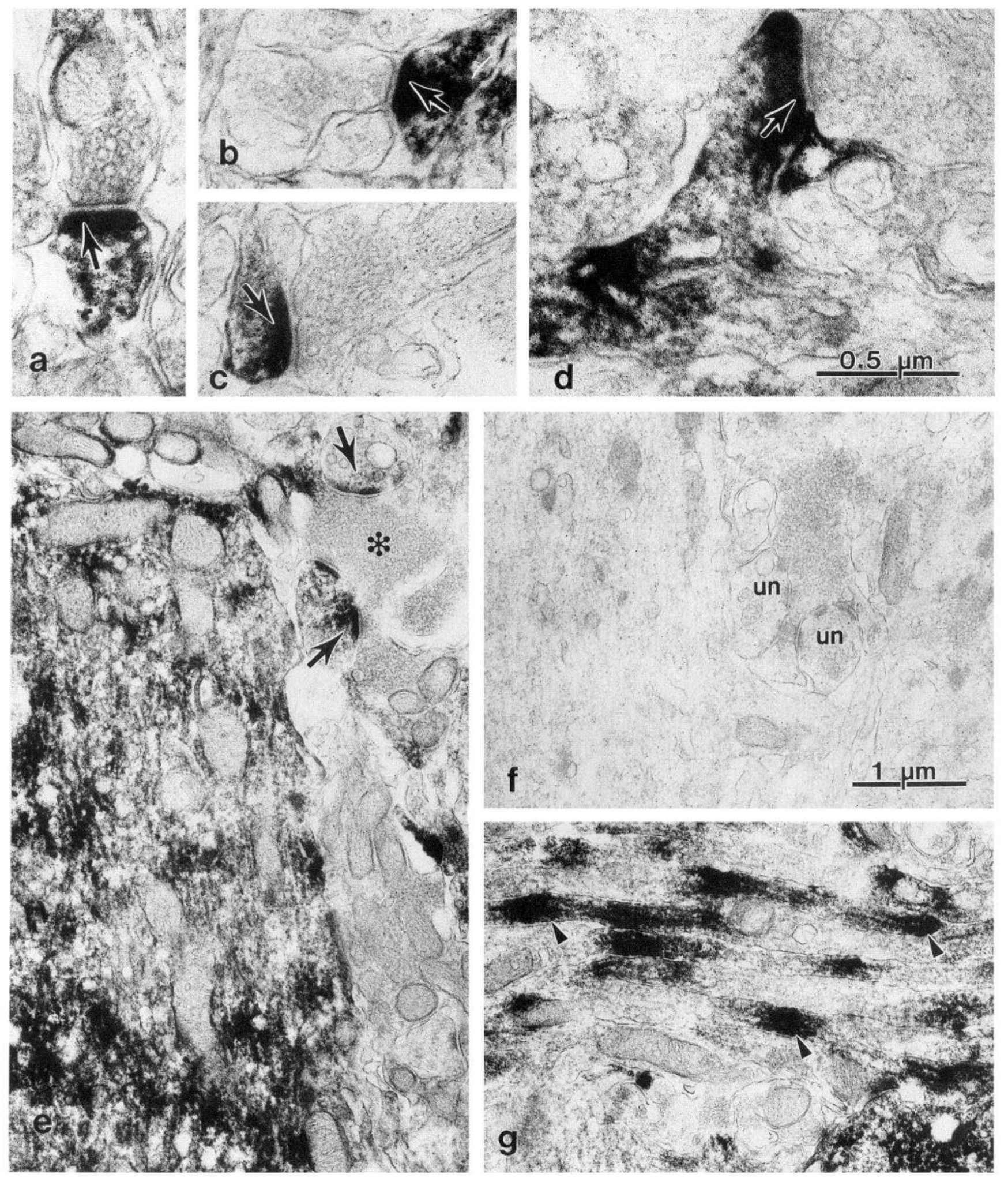

Figure 11. Electron micrographs of hippocampus. Immunostaining with antibody to NR2A/B shown in micrographs $a-e$ and $g$. $a-d$, Dense staining in postsynaptic densities (arrows) in dendritic spines in the stratum oriens $(a, b)$ and molecular layer $(c, d)$ of CA2 $(a, d)$ and CA3 $(b, c)$ regions. $e$, Presumed apical dendrite of pyramidal cell of CA3 region with dense patches of immunostaining. Note staining (not common) in postsynaptic densities (arrows) of specialized spines apposed to mossy fiber terminal (asterisk). $f$, Corresponding control section (no primary antibody) shows complete absence of immunostaining in dendrite (left half of micrograph) and specialized spine synapses (un) of CA3 region. $g$, Patches of staining (arrowheads) in unmyelinated axons of CA3 region. Magnification: $e-g, 20,000 ; a-d, 50,000 \times$. 

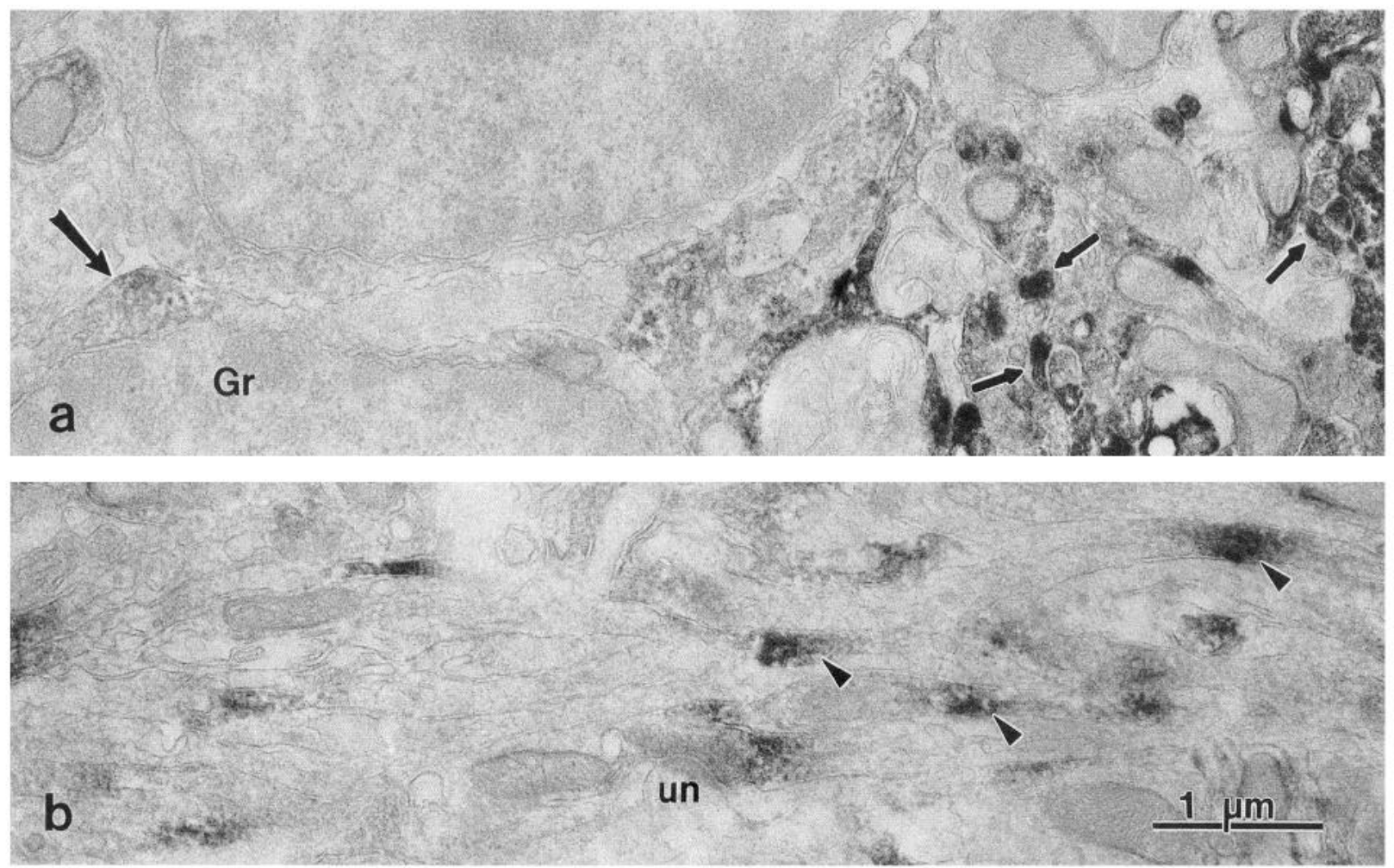

Figure 12. Electron micrographs of cerebellar cortex, immunostained with antibody to NR2A/B. $a$, Granular layer showing dense staining in some processes of a presumptive pinceau (small arrows) and light staining (large arrow) in cytoplasm of a granule cell (Gr). $b$, Molecular layer showing patches of staining (arrowheads) in presumed parallel fibers. un, unstained parallel fiber synapse. Magnification, $20,000 \times$.

\section{Discussion}

In this study we developed an antibody to the C-terminus of NR2A that reacts intensely with both NR2A and NR2B on immunoblots of transfected cell membranes and labels a single band that comigrates with the NR2A and NR2B subunits in rat brain tissues. Since four and six of the 20 amino acid residues of the sequence used for producing the antibody are identical in NR2C and NR2D-2, respectively, we performed immunoblot analysis of membranes of cell transfected with these subunits, and found a weak reaction with both NR2C and NR2D-2. Corresponding labeling of bands in rat tissues, particularly cerebellum where NR2C is most abundant and in hindbrain where NR2D is most abundant, was not seen. This lack of labeling is likely due to the low affinity of the antibody for the NR2C and NR2D-2 subunits or may indicate a relatively low expression of these subunits in brain. Based on these results we interpret our immunocytochemical labeling to represent primarily the NR2A and NR2B subunits. This is supported by the fact that the antibody gives rather weak labeling in the cerebellum, where $\mathrm{NR} 2 \mathrm{C}$ is most abundantly expressed. However, we cannot rule out the possibility that in some populations of neurons, NR2C and NR2D-2 are abundantly expressed, and our labeling reflects primarily these subunits.

The similarity of this distribution to that of antibody to NR1 (Petralia et al., 1994) indicates that NR1 and NR2 colocalize in most neurons in the CNS, as indicated in in situ hybridization studies (Monyer et al., 1992; Nakanishi, 1992; Ishii et al., 1993). This is consistent with physiological studies that support the presence of functional NMDA receptors in most structures in the CNS (discussed in Stone and Burton, 1988; Collingridge and Lester, 1989; Petralia et al., 1994). Ultrastructural distribution of NR2 was also similar to that of NR1, with staining most commonly found in dendrites and postsynaptic membranes and densities. Any differences in staining density in individual structures examined with light or electron microscopy may reflect differences in distribution and/or different ratios of NR1:NR2 subunits in various portions of individual neurons. The widespread distribution of NR1 and NR2A/B antibody staining in neuronal populations implies colocalization with other glutamate receptor types throughout the nervous system (see discussion in Petralia et al., 1994); this supports a model in which postsynaptic membranes contain non-NMDA receptors for fast excitatory transmission and NMDA receptors that modify the response (Bekkers and Stevens, 1989; Jones and Baughman, 1991; Riquelme et al., 1993).

\section{Comparison to in situ hybridization and ligand binding studies}

The pattern of immunostaining with antibody to NR2A/B corresponds to the combined patterns of mRNA distribution of NR2A and NR2B, with a possible contribution of NR2C and NR2D (Monyer et al., 1992; Nakanishi, 1992; Watanabe et al., 1992, 1993; Ishii et al., 1993). For example, substantial staining in some neuron populations of midbrain and hindbrain corresponds to significant mRNA levels of NR2A, such as in the pontine nuclei, inferior colliculus, and inferior olive (Ishii et al., 1993). Staining in some structures such as hypothalamus and spinal cord, where little or no mRNA for NR2A and NR2B has been detected, could reflect the presence of NR2C or NR2D 
(Monyer et al., 1992; Ishii et al., 1993; Tölle et al., 1993; Watanabe et al., 1993). The lower staining with NR2A/B antibody than with NR 1 antibody in many neuron types throughout many regions of the brain may correspond to the apparent high expression of mRNA for NR 1 compared overall to NR2A-NR2D, as illustrated for many forebrain structures (Monyer et al., 1992; Nakanishi, 1992), possibly indicating (1) the expression of NMDA receptor complexes with high NR1:NR2 ratios, (2) additional expression of monomeric NR1 receptor complexes, and/ or (3) a higher cytoplasmic pool of NR1. However, lower staining seen in some structures that contain a predominance of NR2D mRNA (i.e., throughout the brain stem; Ishii et al., 1993) may be due to low detection of NR2D protein by our antibody, as indicated on immunoblots, or to a predominance of mRNA for NR2D-1, which is not detected by our antibody. The presence of dense staining with NR1 antibody in cerebellar Purkinje cells, compared to little or no staining with NR2A/B antibody, is supported by in situ hybridization studies indicating significant mRNA for NR1 in Purkinje cells (Moriyoshi et al., 1991) compared to apparently little or no mRNA for NR2 subunits in Purkinje cells. Also, it is consistent with physiological studies indicating that Purkinje cells in adult animals do not have functional NMDA receptors (i.e., since monomeric NR1 receptors show little functional response; Moriyoshi et al., 1991 ; discussed in Petralia et al., 1994). The low levels of NR2 protein sometimes seen in Purkinje cells in our study may be nonspecific since similar levels sometimes were seen in preadsorption controls. However, cell level studies of NR2 mRNA distribution in the cerebellum have not been published, and we cannot rule out that one or more NR2 subunits are present in low amounts in some Purkinje cells.

As with the antibody to NR1, the widespread distribution of NR2A/B antibody is consistent overall with data from NMDA ligand binding studies, and has been discussed in detail for NR1 antibody (Petralia et al., 1994). As also noted in that article (see also Monaghan et al., 1993) and demonstrated by pharmacological/binding studies of subunit expression in cell cultures and oocytes (Buller et al., 1993; Marti et al., 1993; Raditsch et al., 1993; Wafford et al., 1993; Yamakura et al., 1993), presence of NMDA receptor complexes made up of NR1 in combination with one or more NR2 subunits may account for many of the differences in ligand binding seen in different regions of the brain. Interestingly, higher dendritic staining with NR2A/B antibody, compared to higher cell body staining with our NR1 antibody, corresponds with higher binding of NMDA-sensitive $\mathbf{L}-{ }^{3} \mathrm{H}$-glutamate in dendritic zones compared to white matter regions and cell body layers (Monaghan and Cotman, 1985), that is, suggesting a direct relationship between NR2 subunit and ligand-binding site distribution.

\section{Cellular distribution}

The dense staining seen with our NR1 and NR2A/B antibodies in many neuron cell bodies could indicate maintenance of a high cytoplasmic pool, as suggested for AMPA receptors (e.g., Petralia and Wenthold, 1992). Immunostaining with antibodies to NR1 and NR2A/B, in many dendrites, dendritic spines, and postsynaptic densities implies that complexes of NR 1/NR2 subunits are present postsynaptic to glutamatergic input. In the cerebral cortex, densely stained postsynaptic densities were less common with NR1 antibody (Petralia et al., 1994) than with NR2A/B antibody, perhaps reflecting a typically lower number of NR1 subunit molecules in the postsynaptic region. This could be due to variations in NR1:NR2A/B ratios in receptor complexes. Alternatively, moderate staining with NR1 antibody could reflect its detection of only four of the NR1 variants, although these four are the major ones expressed in rat brain (Sugihara et al., 1992). In the hippocampus, the intense postsynaptic labeling of many small spine synapses with NR2A/B antibody complements the widespread distribution of staining for NR1 in similar synapses, thus supporting numerous studies showing NMDA receptor-mediated long term potentiation (LTP) in both CA1 and CA3 regions (discussed in Zalutsky and Nicoll, 1990; Malenka and Nicoll, 1993; Petralia et al., 1994). In postsynaptic densities apposed by mossy fiber terminals in the CA3 region of the hippocampus, immunostaining was typically low with either NR1 or NR2A/B antibodies, although dense staining with antibody to NR2A/B was seen in a few active zones. This is generally consistent with the presence of only NMDA-independent LTP in this synaptic population (e.g., Zalutsky and Nicoll, 1990), although the data suggest the presence of limited populations of NR1 and NR2 subunits. Differential staining of outer and inner portions of the dentate gyrus molecular layer implies that different levels of NR2 subunits are associated with different inputs onto granule cell dendrites (see discussion for NR1; Petralia et al., 1994). The pattern of staining with NR2 antibody, that is, denser staining in the outer portion, differs from that described in some studies with NR1 antibodies (polyclonal NR1: Pctralia ct al., 1994; monoclonal NR1: Sicgel ct al., 1994; R. S. Petralia, Y.-X. Wang, and R. J. Wenthold, unpublished observations), but resembles that described in another (polyclonal NR1: Brose et al., 1993). Differences between the staining with our NR2 antibody and that of NR 1 antibodies can be attributed to the presence of different ratios of NR1:NR2 associated with different inputs. The similarity of our NR2 antibody staining to that of one of the polyclonal NR1 antibodies (Brose et al., 1993) may be due to preferential recognition of different subunit variants by different antibodies. In sections of cerebellar cortex immunostained with antibody to NR2A/B, the infrequency of stained, postsynaptic densities in presumptive Purkinje cell spines apposed to parallel fibers is consistent with the typically low staining of Purkinje cells. The few examples of stained densities may represent a minor subpopulation of Purkinje cell spines containing NR2 subunits. The significant staining for NR 1 and NR2A/B of presumptive parallel fibers in the molecular layer may account for at least part of the high levels of NR1 and NR2 mRNA found in the granular layer (Moriyoshi et al., 1991; Monyer et al., 1992; Ishii et al., 1993; Watanabe et al., 1993), that is, NR2 protein expressed in the axons of the granule cells. Nevertheless, there is considerable evidence for NMDA receptors at granule cell-mossy fiber synapses (e.g., Silver et al., 1992), although staining of these syrapses with NR1 and NR2A/B antibodies was not definitive. This low staining may be due, at least partly, to the low detection of NR2C by NR2A/B antibody, since NR2C mRNA is high in the granular layer (Ishii et al., 1993). Staining with NR2A/B antibody of the pinceau may be due to cross-reaction with another antigen, that is, a protein that is highly localized to the pinceau (Tigyi et al., 1990), or indicate that molecular layer basket cells contain NR2. Presence of NR2 mRNA in molecular layer cells has not been described; substantial mRNA has been described only in the granular layer (Ishii et al., 1993; Watanabe et al., 1993). A preliminary report describes immunostaining of molecular layer cells with an NR2C. antibody (Mulac-Jericevic et al., 1993), but these results have not been corroborated. 


\section{References}

Akinci MK, Johnston GAR (1993) Sex differences in acute swim stress-induced changes in the binding of MK-801 to the NMDA subclass of glutamate receptors in mouse forebrain. J Neurochem 61: 2290-2293.

Alford S, Dubuc R (1993) Glutamate metabotropic receptor mediated depression of synaptic inputs to lamprey reticulospinal neurones. Brain Res 605:175-179.

Anantharam V, Panchal RG, Wilson A, Kolchine VV, Treistman SN, Bayley $H$ (1992) Combinatorial RNA splicing alters the surface charge on the NMDA receptor. FEBS Lett 305:27-30.

Armstrong WE (1985) Hypothalamic supraoptic and paraventricular nuclei. In: The rat nervous system, Vol 1 (Paxinos G, ed), pp 119128. New York: Academic.

Bekkers JM, Stevens CF (1989) NMDA and non-NMDA receptors are co-localized at individual excitatory synapses in cultured rat hippocampus. Nature 341:230-233.

Brose N, Gasic GP, Vetter DE, Sullivan JM, Heinemann SF (1993) Protein chemical characterization and immunocytochemical localization of the NMDA receptor subunit NMDA R1. J Biol Chem 268: 22663-22671.

Buller AL, Morrisett RA, Monaghan DT (1993) The NR2 subunit contributes to the pharmacological diversity of native NMDA receptors. Soc Neurosci Abstr 19:1356.

Burgoyne RD, Graham ME, Cambray-Deakin M (1993) Neurotrophic effects of NMDA receptor activation on developing cerebellar granule cells. J Neurocytol 22:689-695.

Cik M, Chazot PL, Stephenson FA (1993) Optimal expression of cloned NMDAR1/NMDAR2A heteromeric glutamate receptors: a biochemical characterization. Biochem J 296:877-883.

Collingridge GL, Lester RAJ (1989) Excitatory amino acid receptors in the vertebrate central nervous system. Pharmacol Rev 41:143-210.

Durand GM, Bennett MVL, Zukin RS (1993) Splice variants of the $N$-methyl-D-aspartate receptor NR1 identify domains involved in regulation by polyamines and protein kinase C. Proc Natl Acad Sci USA 90:6731-6735.

Furuyama T, Kiyama H, Sato K, Park HT, Maeno H, Takagi H, Tohyama M (1993) Region-specific expression of subunits of ionotropic glutamate receptors (AMPA-type, KA-type and NMDA receptors) in the rat spinal cord with special reference to nociception. Mol Brain Res 18:141-151.

Hollmann M, Boulter J, Maron C, Bcaslcy L, Sullivan J, Pccht G, Heinemann S (1993) Zinc potentiates agonist-induced currents at certain splice variants of the NMDA receptor. Neuron 10:943-954.

Hönack D, Löscher W (1993) Sex differences in NMDA receptor mediated responses in rats. Brain Res 620:167-170.

Ikeda K, Nagasawa M, Mori H, Araki K, Sakimura K, Watanabe M, Inoue Y, Mishina M (1992) Cloning and expression of the $\epsilon 4$ subunit of the NMDA receptor channel. FEBS Lett 313:34-38.

Ishii T, Moriyoshi K, Sugihara H, Sakurada K, Kadotani H, Yokoi M, Akazawa C, Shigemoto R, Mizuno N, Masu M, Nakanishi S (1993) Molecular characterization of the family of the $N$-methyl-D-aspartate receptor subunits. J Biol Chem 268:2836-2843.

Itano Y, Murayama T, Kitamura Y, Nomura Y (1992) Glutamate inhibits adenylate cyclase activity in dispersed rat hippocampal cells directly via an $N$-methyl-D-aspartate-like metabotropic receptor. J Neurochem 59:822-828.

Jones KA, Baughman RW (1991) Both NMDA and non-NMDA subtypes of glutamate receptors are concentrated at synapses on cerebral cortical neurons in culture. Neuron 7:593-603.

Karp SJ, Masu M, Eki T, Ozawa K, Nakanishi S (1993) Molecular cloning and chromosomal localization of the key subunit of the human $N$-methyl-D-aspartate receptor. J Biol Chem 268:3728-3733.

Kirkwood A, Dudek SM, Gold JT, Aizenman CD, Bear MF (1993) Common forms of synaptic plasticity in the hippocampus and neocortex in vitro. Science 260:1518-1521.

Kumar KN, Tilakaratne N, Johnson PS, Allen AE, Michaelis EK (1991) Cloning of cDNA for the glutamate-binding subunit of an NMDA receptor complex. Nature 354:70-73.

Kusiak JW, Norton DD (1993) A splice variant of the $N$-methyl-Daspartate (NMDAR1) receptor. Mol Brain Res 20:64-70.

Kutsuwada T, Kashiwabuchi N, Mori H, Sakimura K, Kushiya E, Araki $\mathrm{K}$, Meguro $\mathrm{H}$, Masaki $\mathrm{H}$, Kumanishi T, Arakawa M, Mishina $\mathbf{M}$ (1992) Molecular diversity of the NMDA receptor channel. Nature $358: 36-41$.
Malenka KC, Nicoll RA (1993) NMDA-receptor-dependent synaptic plasticity: multiple forms and mechanisms. Trends Neurosci 16:521527.

Marti T, Benke D, Mertens S, Heckendorn R, Pozza M, Allgeier H, Angst C, Laurie D, Seeburg P, Mohler H (1993) Molecular distinction of three $N$-methyl-D-aspartate-receptor subtypes in situ and developmental receptor maturation demonstrated with the photoaffinity ligand ${ }^{125}$ I-labeled CGP 55802A. Proc Natl Acad Sci 90:8434-8438.

Martin LJ, Blackstone CD, Levey AI, Huganir RL, Price DL (1993) AMPA glutamate receptor subunits are differentially distributed in rat brain. Neuroscience 53:327-358.

Mattson MP, Kumar KN, Wang H, Cheng B, Michaelis EK (1993) Basic FGF regulates the expression of a functional $71 \mathrm{kDa}$ NMDA receptor protein that mediates calcium influx and neurotoxicity in hippocampal neurons. J Neurosci 13:4575-4588.

Meguro H, Mori $\mathrm{H}$, Araki K, Kushiya E, Kutsuwada T, Yamazaki M, Kumanishi T, Arakawa M, Sakimura K, Mishina M (1992) Functional characterization of a heteromeric NMDA receptor channel expressed from cloned cDNAs. Nature 357:70-74.

Monaghan DT, Cotman CW (1985) Distribution of $N$-methyl-n-aspartate-sensitive $L_{-}-\left[{ }^{3} \mathrm{H}\right]$ glutamate-binding sites in rat brain. $\mathbf{J}$ Neurosci 5:2909-2919.

Monaghan DT, Bridges RJ, Cotman CW (1989) The excitatory amino acid receptors: their classes, pharmacology, and distinct properties in the function of the central nervous system. Annu Rev Pharmacol Toxicol 29:365-402

Monaghan DT, Clark HC, Schneider BE (1993) Distributions of NMDA receptor subtypes correspond to specific receptor subunits. Soc Neurosci Abstr 19:1356.

Monyer H, Sprengel R, Schoepfer R, Herb A, Higuchi M, Lomeli H, Burnashev N, Sakmann B, Seeburg PH (1992) Heteromeric NMDA receptors: molecular and functional distinction of subtypes. Science 256:1217-1221.

Mori H, Yamakura T, Masaki H, Mishina M (1993) Involvement of the carboxyl-terminal region in modulation by TPA of the NMDA receptor channel. Neuroreport 4:519-522.

Moriyoshi K, Masu M, Ishii T, Shigemoto R, Mizuno N, Nakanishi S (1991) Molecular cloning and characterization of the rat NMDA receptor. Nature 354:31-37.

Mugnaini E (1972) The histology and cytology of the cerebellar cortex. In: The comparative anatomy and histology of the cerebellum: the human cerebellum, cerebellar connections, and cerebellar cortex (Larsell O, Jansen J, eds), pp 201-251. Minneapolis: University of Minnesota.

Mulac-Jericevic B, Benke TA, Peterson NL, Angelides KJ (1993) Distribution of NMDA receptor subunits on rat hippocampal, cerebellar and cortical neurons in culture and in brain slices using subunit specific antibodies. Soc Neurosci Abstr 19:1355.

Nakanishi N, Axel R, Shenider NA (1992) Alternative splicing generates functionally distinct $N$-methyl-D-aspartate receptors. Proc Natl Acad Sci 89:8552-8556.

Nakanishi S (1992) Molecular diversity of glutamate receptors and implications for brain function. Science 258:597-603.

Okamoto N, Hori S, Akazawa C, Hayashi Y, Shigemoto R, Mizuno N, Nakanishi S (1994) Molecular characterization of a new metabotropic glutamate receptor mGluR7 coupled to inhibitory cyclic AMP signal transduction. J Biol Chem 269:1231-1236.

Palay SL, Chan-Palay V (1974) Cerebellar cortex: cytology and organization. New York: Springer

Paxinos G, Watson C (1986) The rat brain in stereotaxic coordinates, 2d ed. New York: Academic.

Peters A, Palay SL, Webster HF (1991) The fine structure of the nervous system, 3d ed. New York: Oxford UP.

Petralia RS, Wenthold RJ (1992) Light and electron immunocytochemical localization of AMPA-selective glutamate receptors in the rat brain. J Comp Neurol 318:329-354.

Petralia RS, Yokotani N, Wenthold RJ (1994) Light and electron microscope distribution of the NMDA receptor subunit NMDAR 1 in the rat nervous system using a selective anti-peptide antibody. J Neurosci 14:667-696.

Planells-Cases R, Sun W, Ferrer-Montiel AV, Montal M (1993) Molecular cloning, functional expression, and pharmacological characterization of an $N$-methyl-D-aspartate receptor subunit from human brain. Proc Natl Acad Sci USA 90:5057-5061.

Raditsch M, Ruppersberg JP, Kuner T, Günther W, Schoepfer R, See- 
burg PH, Jahn W, Witzemann V (1993) Subunit-specific block of cloned NMDA receptors by $\operatorname{argiotoxin}_{636}$. FEBS Lett 324:63-66.

Riquelme G, Wyneken U, Villanueva S, Orrego F (1993) Recordings of glutamate receptor channels in isolated postsynaptic densities. Neuroreport 4:1163-1166.

Sato K, Kiyama H, Park HT, Tohyama M (1993) AMPA, KA and NMDA receptors are expressed in the rat DRG neurones. Neuroreport 4:1263-1265.

Saugstad JA, Kinzie JM, Segerson TP, Westbrook GL (1993) Characterization of a new metabotropic glutamate receptor (MGLUR7) homologous to the AP4 receptor (MGLUR4). Soc Neurosci Abstr 19: 68.

Seeburg PH (1993) The molecular biology of mammalian glutamate receptor channels. Trends Neurosci 16:359-365.

Shigemoto R, Ohishi H, Nakanishi S, Mizuno N (1992) Expression of the mRNA for the rat NMDA receptor (NMDAR1) in the sensory and autonomic ganglion neurons. Neurosci Lett 144:229-232.

Siegel, SJ, Brose N, Janssen WG, Gasic GP, Jahn R, Heinemann SF (1994) Regional, cellular, and ultrastructural distribution of $N$-methyl-D-aspartate receptor subunit 1 in monkey hippocampus. Proc Natl Acad Sci 91:564-568.

Silver RA, Traynelis SF, Cull-Candy SG (1992) Rapid-time-course miniature and evoked excitatory currents at cerebellar synapses in situ. Nature 355:163-166.

Smirnova T, Stinnakre J, Mallet J (1993a) Characterization of a presynaptic glutamate receptor. Science $262: 430-433$.

Smirnova T, Laroche S, Errington ML, Hicks AA, Bliss TVP, Mallet J (1993b) Transsynaptic expression of a presynaptic glutamate receptor during hippocampal long-term potentiation. Science 262:433436.

Standaert DG, Testa CM, Penney JB Jr, Young AB (1993) Alternatively spliced isoforms of the NMDAR 1 glutamate receptor subunit: differential expression in the basal ganglia of the rat. Neurosci Lett 152:161-164.

Stern P, Béhé P, Schoepfer R, Colquhoun D (1992) Single-channel conductances of NMDA receptors expressed from cloned cDNAs: comparison with native receptors. Proc R Soc Lond [Biol] 250:271277.

Stone TW, Burton NR (1988) NMDA receptors and ligands in the vertebrate CNS. Prog Neurobiol 30:333-368.

Sucher NJ, Brose N, Deitcher DL, Awobuluyi M, Gasic GP, Bading H, Cepko CL, Greenberg ME, Jahn R, Heinemann SF, Lipton SA (1993) Expression of endogenous NMDAR1 transcripts without recepto protein suggests post-transcriptional control in PC12 cells. J Biol Chem 268:22299-22304.
Sugihara H, Moriyoshi K, Ishii T, Masu M, Nakanishi S (1992) Structures and properties of seven isoforms of the NMDA receptor generated by alternative splicing. Biochem Biophys Res Commun 185: 826-832.

Tigyi G, Matute C, Miledi R (1990) Monoclonal antibodies to cerebellar pinceau terminals obtained after immunization with brain mRNA-injected Xenopus oocytes. Proc Natl Acad Sci USA 87:528532.

Tingley WG, Roche KW, Thompson AK, Huganir RL (1993) Regulation of NMDA receptor phosphorylation by alternative splicing of the C-terminal domain. Nature 364:70-73.

Tölle TR, Berthele A, Zieglgänsberger W, Seeburg PH, Wisden W (1993) The differential expression of 16 NMDA and non-NMDA receptor subunits in the rat spinal cord and in periaqueductal gray. J Neurosci 13:5009-5028.

Ultsch A, Schuster CM, Laube B, Betz H, Schmitt B (1993) Glutamate receptors of Drosophila melanogaster primary structure of a putative NMDA receptor protein expressed in the head of the adult fly. FEBS Lett 324:171-177.

Wafford KA, Bain CJ, Bourdelles BL, Whiting PJ, Kemp JA (1993) Preferential co-assembly of recombinant NMDA receptors composed of three different subunits. Neuroreport 4:1347-1349.

Watanabe M, Inoue Y, Sakimura K, Mishina M (1992) Developmental changes in distribution of NMDA receptor channel subunit mRNAs. Neuroreport 3:1138-1140.

Watanabe M, Inoue Y, Sakimura K, Mishina M (1993) Distinct distributions of five $N$-methyl-D-aspartate receptor channel subunit mRNAs in the forebrain. J Comp Neurol 338:377-390.

Wenthold RJ, Yokotani N, Doi K, Wada K (1992) Immunochemical characterization of the non-NMDA glutamate receptor using subunitspecific antibodies: evidence for a hetero-oligomeric structure in rat brain. J Biol Chem 267:501-507.

Wenthold RJ, Trumpy VA, Zhu WS, Petralia RS (1994) Biochemical and assembly properties of GluR6 and KA2, two members of the kainate receptor family, determined with subunit-specific antibodies. J Biol Chem 269:1332-1339.

Yamakura T, Mori H, Masaki H, Shimoji K, Mishina M (1993) Different sensitivities of NMDA receptor channel subtypes to non-competitive antagonists. Neuroreport 4:687-690.

Yamazaki M, Mori H, Araki K, Mori KJ, Mishina M (1992) Cloning, expression and modulation of a mouse NMDA receptor subunit. FEBS Lett 300:39-45.

Zalutsky RA, Nicoll RA (1990) Comparison of two forms of longterm potentiation in single hippocampal neurons. Science 248:16191624 . 